\title{
A DOUBLE-EDGED SWORD? THE ANTIPODAL EFFECTS OF INSTITUTIONAL DISTANCE ON PARTNER SELECTION IN CROSS-BORDER ALLIANCES
}

SORIN M.S. KRAMMER

Leeds University Business School

University of Leeds

Maurice Keyworth Building

Leeds LS2 9JT

United Kingdom

E-mail: M.S.Krammer@leeds.ac.uk 


\begin{abstract}
Careful partner selection is a prerequisite for successful alliances. I posit that institutional distance will influence partner selection in international technological alliances negatively for exploitation, and positively for exploration alliances. A longitudinal dataset of firms in the global tire industry confirms firms' preference for similar cognitive, normative, and regulatory partners in exploitation alliances, and a preference for dissimilar partners in exploration alliances. However, the latter is true for differences across the regulative and cognitive pillars rather than for normative differences. These findings attest to the antipodal role of institutional differences in the selection of prospective partners for cross-border technological alliances.
\end{abstract}




\section{A DOUBLE-EDGED SWORD? THE ANTIPODAL EFFECTS OF INSTITUTIONAL DISTANCE ON PARTNER SELECTION IN CROSS-BORDER ALLIANCES}

\section{INTRODUCTION}

Technological alliances have become a popular strategy over the last decades (Gulati, 1995a; Anand \& Khanna, 2000; Rothaermel \& Boeker, 2008). Firms form explorative and exploitative alliances (Lavie \& Rosenkopf, 2006; Sarala, Junni, Cooper \& Tarba, 2014) to access complementary technologies (Prahalad \& Hamel, 1990), reduce uncertainty (Burgers, Hill \& Kim, 1993), enter new markets (García-Canal, Valdés-Llaneza, \& Sánchez-Lorda, 2008), spur performance (Yamakawa, Yang \& Lin, 2011), or improve their strategic options (Weber \& Tarba, 2014). However, as firms rush to leverage these benefits, they often ignore potential losses from alliance mismatches (Ireland, Hitt \& Vaidyanath, 2002) that ultimately result in high failure rates (Park \& Ungson, 1997; Kale, Dyer \& Singh, 2002). To avoid such outcomes, firms must carefully select their partners (Shah \& Swaminathan, 2008), especially in international settings (Dacin, Hitt \& Levitas, 1997; Dong \& Glaister, 2006).

Employing elements from transaction costs economics (TCE) and resource-based theory (RBV), prior studies show that successful selection of alliance partners depends on the complementarity between them in terms of characteristics and resources (Hitt et al., 2000; Hitt et al., 2004; Rothaermel \& Boeker, 2008). Others suggest that, despite this need for complementarity, partners must share compatible skills, routines, and strategies for the alliance to function well (Dacin et al., 1997; Glaister, 1996). Besides the individual characteristics of partnering firms, alliances are also subject to agency problems arising from misalignment of partners' goals (Einsenhardt, 1989), separation of ownership and control mechanisms (Reuer \& Ragozzino, 2006) and project-specific behavior of partners (Shah \& Swaminathan, 2008). Thus, the uncertainty firms 
face (Beckman, Haunschild \& Philips, 2004), level of mutual trust (Gulati, 1995a; Anand \& Khanna, 2000), social and strategic interdependence (Gulati, 1995b), product and technological relatedness (Krammer, 2016), as well as prior commitments to the alliance (Mohr \& Spekman, 1994) have all important implications for the selections of partners.

In addition to the above firm-specifics, the selection of alliance partners in an international context needs to overcome idiosyncratic differences between countries stemming from economic, political, legislative, and social factors (Hitt et al., 2000; Parkhe, 2003). Firm behavior does not occur in an organizational vacuum (Dacin, Ventresca \& Beal, 1999) but is rather nested in the institutional environment in which it operates (Brouthers \& Brouthers, 2000; Meyer et al., 2009; Ambos \& Håkanson, 2014; Krammer, Strange, \& Lashitew, 2018). As a result, institutional distance between home and host country plays an important role in determining different elements of MNE strategy, such as entry modes (Lu, 2002), staffing (Gaur, Delios \& Singh, 2007), inter-firm collaborations (Park \& Ungson, 1997) or export activities (He, Brouthers \& Filatotchev, 2013).

Given the existing institutional heterogeneity worldwide (Meyer et al., 2009), it is important to understand how institutional distance affects MNE's selection of strategic partners (Hitt et al., 2005). However, with few exceptions, this issue has yet to receive significant attention in the literature. For example, Hitt et al. (2000) identify significant differences in competences sought from foreign partners between firms from emerging (i.e., financial resources, assets, technologies) and developed economies (i.e., unique competences, local market knowledge). Moreover, Hitt et al. (2004) point out that institutional differences are important even among emerging economies themselves, and contrast their effects on the partnering preferences of Chinese versus Russian managers. These inherent differences are confirmed by more recent studies focusing on the Indian (Chand \& Katou, 2012) and Chinese subnational contexts (Ahlstrom et al., 2014). Finally, Roy \& Oliver (2009) show that the selection of foreign partners is contingent on the host-countries' regulatory environments, such as the rule of law or control of corruption. While all these studies 
provide important foundations for understanding the role of institutions in the selection of alliance partners, they also exhibit important limitations in terms of generality and scope by being confined to few countries and/or single institutional dimensions that fail to capture compellingly the considerable institutional heterogeneity across the world (Hitt et al., 2004) and its subsequent effects on different types of inter-firm alliances (Kale \& Singh, 2009).

In response to these challenges, I explore partner selection for alliances through the lens of TCE theory (Gulati \& Singh, 1998), supplemented by institutional (Kostova, 1999) and learning (Grant \& Baden-Fuller, 2004) rationales. Once a firm identifies a pool of possible international partners that are committed, compatible and complementary, it must decide which one(s) to actually partner with, and I content that, in addition to firm-specific factors, country-specific rationales will also play an important role in this process (Parkhe, 1991). Specifically, I propose that firms seeking exploitation will prefer partners from closer cognitive and normative environments and similar or superior regulatory ones, given coordination concerns, absorptive capacity issues, and appropriation risks that can affect the transfer of technologies and the potential for rents from these alliances (Gulati \& Singh, 1998; Michailova \& Hutchings, 2006; Delerue \& Simon, 2009; Belderbos, Jacob, \& Lokshin, 2018). In turn, I suggest that institutional distance will relate positively to selection of partners for exploration, given the increased opportunities for learning, cross-feeding, pooling of resources, institutional arbitrage, and lower risks of leakages (Gimeno, 2004; Noteboom et al., 2007; Nathan \& Lee, 2013).

These hypotheses are tested using a hand-collected dataset that covers all firms in the global tire industry and their alliances between 1985 and 2003. Following previous studies in this area, I focus on horizontal agreements (Mowery et al., 2002; Lavie \& Rosenkopf, 2006) for both theoretical clarity (Phelps, 2010) and consistency with the particularities of this industry, in which technological alliances occur almost exclusively between tire producers (Acha \& Brusoni, 2005). 
The results of the empirical analysis broadly support my conjectures regarding the antipodal effects of institutional distance on the selection of international alliance partners.

Accordingly, this work proposes several contributions. First, it advances the alliance literature by theorizing and testing the importance of environmental contingencies, in this case of institutional nature, in the process of partner selection. While most prior studies on the selection process have paid significant attention to the firm-specific contingencies (Shah \& Swaminathan, 2008; Yamakawa et al., 2011; Weber \& Tarba, 2014), our knowledge on the mechanisms through which external environments may affect these choices is still very limited, particularly in terms of generality and international scope (Ahlstrom et al., 2014). By examining how different institutional environments affect the selection of partners in a truly global context (i.e., numerous home and home countries), it offers more comprehensive explanations for this phenomenon that advance significantly this stream of literature (Hitt et al., 2000; Hitt et al., 2004; Roy \& Oliver, 2009).

The second contribution is to examine the process of partner selection by focusing on learning objectives of the alliance as an important inducement of this process. In doing so, I distinguish between exploitation alliances, which involve the use of technologies already known (March, 1991), and explorative ones that aim to develop new technologies or competences for securing new strategic opportunities (Koza \& Lewin, 1998). Given these fundamental differences, my theoretical arguments suggest that institutional distance will have antipodal effects on the appeal of partners for exploitative versus explorative interactions. Together these insights extend TCE theory by expounding mechanisms through which the institutional background of prospective partners may become either a benefit or a liability for a technological alliance, contingent on the latter's learning objectives.

Third, I differentiate the concomitant effects of several institutional pillars on partnering decisions, given their different, yet complementary, nature (Scott, 2001). Exploitation of technological assets via alliances involves unidirectional transfer of technology from one (focal) 
firm to its partner(s); as such, it is sensitive to normative (Steensma et al., 2000), regulatory (Oxley, 1999) and cognitive (Kelly, Schaan \& Joncas, 2002) differences between partners, which may entail additional costs or opportunities for such alliance. In contrast, institutionally-distant partners will be more appealing for exploration given firms' need to diversify and complement each other's knowledge (Schildt et al., 2005). The empirical results broadly support these antipodal effects of different institutional pillars on selection of partners for exploitation versus exploration alliances, with the exception of differences in terms normative institutions, which appear to hinder both types of endeavors. Consequently, these results support the idea of complex interactions between institutions and firm strategies across different institutional pillars, and advance our knowledge on these issues by proposing and testing the "double-edged sword" effect of institutional distance on partner selection for alliances.

\section{BACKGROUND AND THEORY}

A central issue for alliance formation is the quest for a suitable partner (Gulati, 1995a; Gulati, 1995b; Hitt et al., 2000). Surveys confirm that most managers see partner selection as the most important factor for alliance success, one that firms should continuously perfect if they are to improve the outcome of their alliances (Glaister, 1996). Whereas a thorough selection procedure involves careful screening and a commitment of substantial resources, it pays major dividends in terms of improving the flow of knowledge, resource and skills into and within the alliance, thereby meaningfully increasing the ability of firms to meet their strategic objectives (Geringer, 1991).

While firm-specific factors (e.g., complementarity, compatibility, trust, strategic interdependence, relatedness) present important explanations for a successful selection of alliance partners, in international transactions, country-specific factors (e.g., differences in economic development, governmental policies) exacerbate the repercussions of a potential mismatch (Dacin 
et al., 1997; Parkhe, 2003; Dong \& Glaister, 2006). Among them, institutional characteristics have been found to be particularly relevant for MNE strategies (Brouthers \& Brouthers, 2000; Kostova \& Zaheer, 1999; Meyer et al., 2009), however such factors have rarely been studied in conjunction with partner selection, let alone in relation to different alliance types in terms of objectives and underlying requirements.

\section{Exploitation and Exploration in Alliances}

Strategic alliances are often formed with the primary purpose of acquiring (i.e., learning and absorbing) or providing (e.g., licensing or exchanging) knowledge to partnering firms (Grant \& Baden-Fuller, 2004). Following March (1991), I distinguish between explorative and exploitative knowledge quests and consider their respective alliance ramifications.

Explorative knowledge involves intense search, high risk, discovery, and the pursuit of novelty. It usually takes the organization away from its established and comfortable knowledge base, which is expressed in its structure and routines, into new domains and unchartered territory. For the firm, exploration holds the promise of long term survival and prosperity, while incurring higher costs and a more risk in the short term (Levinthal \& March, 1993). Missing on essential tacit knowledge, a firm that undertakes an exploratory search has to look outside its boundaries and beyond its traditional environmental confines; an alliance partner possessing diverse tacit knowledge is likely a suitable source for such knowledge needs (Schildt, Maula \& Keil, 2005, Phelps, 2010; Krammer, 2016).

In contrast, exploitation triggers a knowledge search that is much more routine, i.e. planned, structured and programmed. This type of search is more focused on process implementation and execution rather than on creating something new. Subsequently, the return on investment for exploitation, at least in the short term, tends to be more certain and visible, with the promise of 
steady and predictable, if modest, gains (March, 1991). Given these features, proximity, relative similarity and ease of coordination will facilitate the efficient knowledge and coordination and execution of exploitative endeavors (Levinthal \& March, 1991; Koza \& Lewin, 1998).

The distinction between explorative and exploitative learning has been applied to strategic alliances (e.g., Koza \& Lewin, 1998), in particular in technology intensive industries where learning and technology attainment are key formation objectives. Thus, alliances have been classified according to their primary purpose for a focal firm, based on whether the knowledge sought from a partner is new, or external to a firm, or is rather intended to leverage and or extend the utilization of existing knowledge assets and competencies (Lavie \& Rosenkopft, 2006; Yamakawa et al., 2011; Sarala et al., 2014; Krammer, 2016). Despite these advances, prior research has not sufficiently explained how the choice of alliance partners may differ in an exploratory versus exploitative setting and the effects of institutional environments in which alliance partners are embedded. These caveats are important because they are intertwined with the strategic objectives of the partners and form a pivotal link between firms and their macro-environment (Grant \& Baden-Fuller, 2004).

\section{Institutional distance and selection of international partners for alliances}

Differences in terms of institutional arrangements across countries can both benefit and impede MNE activities abroad. On one hand, these differences present opportunities for institutional arbitrage, encouraging exploitation of different capabilities across countries and institutional regimes (Gaur \& Lu, 2007; Krammer, 2017; Krammer et al., 2018). On the other, institutional differences contribute to the liability of foreignness faced by the MNEs in the form of unfamiliarity, relational and discriminatory hazards that require additional costs of adaptation to foreign host environments (Eden \& Miller, 2004). As a result, institutional distance between home 
and host countries is a good predictor for MNE's strategies in different host markets (Henisz \& Swami Nathan, 2008).

Concerning partner selection, the impact of institutional distance has received relatively little attention, and existing contributions have been confined to few countries and single institutional dimensions (Hitt et al. 2000; Hitt et al. 2004; Roy \& Oliver 2009; Shi et al., 2012). Nevertheless, institutional complexity requires a complete examination of all dimensions (i.e., cognitive, normative and regulatory) given their potentially different effects and magnitudes on various MNE activities. Furthermore, exploitation and exploration through strategic alliances are likely to be affected differently by institutional differences between partners.

Whereas the bulk of the literature views differences in culture and institutions as detrimental to cross-border business (Stahl \& Tung, 2014), scholars (e.g., Parkhe, 1991) have pointed out that such differences can also be beneficial. Some suggestions have been made as to when differences were likely to produce a benefit or a handicap, however those proposals have centered on the differences in each set of features, and their complementarity or conflict potential (Shenkar \& Zeira, 1992). Still, studies have not dwelled on how institutional differences matter to different types of alliances based on their strategic learning aims, in this case, on how exploration versus exploitation might produce a different impact for institutional gaps. Therefore, our understanding of these issues could be improved by focusing on the three pillars of institutional distance proposed by Kostova (1999) -i.e., cognitive, normative and regulatory- and distinguishing between these two central types of alliances (March, 1991). In this way, this study can provide a more comprehensive answer regarding the effects of different institutional factors on partner selection, and their relative importance for MNEs seeking technological allies.

My starting point is that explorative and exploitative alliances are fundamentally different in nature and should therefore relate differentially to institutional differences between prospective 
partners. Institutional differences can be identified across three areas, often referred to as institutional "pillars" (Scott, 2001). The first two (i.e., normative and cognitive) pillars capture tacit and informal aspects that describe how societal actors operate in a certain environment (Gaur et al., 2007). Normative aspects describe legitimate ways to achieve goals (Scott, 2001), while cognitive aspects reflect different schemas, frames, beliefs and inferences on how the world operates (Kostova, 1999). Both reflect institutional aspects that are deeply embedded in the normal functioning of a society. Thus, firms' actions are highly representative of their home normativecognitive environments since they often abide and implement these rules unconsciously (He et al., 2013).

Nevertheless, given their similarity and overlap, distinguishing between cognitive and normative aspects of institutions in practice is a daunting task (Scott, 2001). The cognitive dimension is commonly identified with cultural values and beliefs (Estrin et al., 2009; Bae \& Salomon, 2010; He et al., 2013). Defined as the "collective programming of the mind" that identifies different groups of people, national culture provides a common frame for individuals to relate to organizations, the environment, and their peers (Hofstede, 1980). In turn, the normative dimension has been closely linked to the development of professional standards and educational curricula, and previous studies have conceptualized it using measures of managerial abilities, norms and practice (Delios \& Beamish, 1999; Xu et al., 2004; He et al., 2013). Thus, I focus on the potential mismatch in terms of managerial norms and cultural values as two cognitive-normative elements that are relevant for the selection of alliance partners. Moreover, I consider cognitive (cultural) and normative (managerial) distance between partners to be symmetric and dyadic in nature (Zaheer, Schomaker, \& Nachum, 2012), enabling me to assess the extent of differences between partners, however without being able to rank them. 
The third (i.e., regulatory) component of the institutional environment includes codified rules that govern economic interactions (North, 1990). These formal institutional components (i.e. laws, regulations, policies) vary significantly across countries, and affect all inter-firm international interactions (Xu \& Shenkar, 2002). Out of many potential institutional elements to be considered, I focus on a specific regulatory aspect, namely intellectual property rights (IPR). IPR are commonly defined as the exclusive rights given to a creator or inventor over the use of it over a limited period of time. Prior studies have shown that IPR regulations are intrinsically linked to innovation performance (Bekkers, Duysters, \& Verspagen, 2002; Krammer, 2009; Cockburn, Lanjouw \& Schankerman, 2016), commercial ability (Arora, Fosfuri \& Gambardella, 2001), ability to capture rents (Khoury \& Peng, 2011), and firm strategies and governance of technological assets and relationships (Zhao, 2006; Hagedoorn \& Hesen, 2007). Thus, given this cardinal influence of IPR on technological aspects, I argue that regulatory differences in terms of IPR will influence partner selection in international alliances with a technological component.

Unlike the cognitive and normative elements of the institutional environment, regulatory distance between home and MNE host country is asymmetric and the direction matters (Zaheer et al., 2012). Thus, in contrast to cognitive-normative distance, for regulatory differences I can assess both how different the two partners are, and which one is better. Albeit globalization and increased economic integration have contributed to the convergence of regulations worldwide, countries still exhibit significant heterogeneity in terms of IPR (Park, 2008; Peng, Ahlstrom, Carraher \& Shi, 2017). Some of these differences involve important IPR aspects such as legal protection, actual enforcement, and coverage of these laws. By considering both the magnitude and the direction of this relationship between countries, I emphasize both how, and how much they differ in terms of IPR regulations. In turn, the magnitude and direction of these IPR differences may favor or hinder alliance activities across borders. Hence, upon considering a set of potential alliance partners, the 
MNE can assess each of them as either having stronger (i.e. positive distance) or weaker (i.e. negative distance) regulatory institutions vis-à-vis its home-country environment.

\section{One Edge of the Sword: Institutional Distance as a Hindrance for Exploitation}

There are several reasons for which MNEs would prefer partners from closer cultural and managerial backgrounds for exploitative technological alliances. First, managers face significant coordination concerns upon establishing new alliances. These concerns stem from increased interdependence between partners and the logistics of alliance activities (Gulati \& Singh, 1998); they include communication and decision costs that are contingent upon the cognitive-normative mismatch of partners (Delerue \& Simon, 2009). Second, cultural and managerial proximity is commonly associated with intrinsic attractiveness and trust, which facilitate the transfer of technology between partners (Michailova \& Hutchings, 2006). Technical knowledge has a major tacit component and is often embedded in people and organizations (Volkof, Strong \& Elmes, 2007), thus trustful and attractive potential partners stand a better chance of being selected as technological allies. Finally, successful assimilation of technology demands certain absorptive capabilities (e.g., trained employees, knowledgeable managers, efficient routines, etc.) from potential collaborators (Mowery et al., 2002). Firms from closer normative-cognitive backgrounds have similar cognitive schemas and managerial dispositions regarding the use and share of technical knowledge, which will be easier to understand and adopt by the MNE (Xu et al., 2004) facilitating also the absorption of technology by partnering firms (Pisano, 1990). Therefore, they will be more appealing as partners for exploitation alliances (Grant \& Baden-Fuller, 2004).

In contrast, more distant firms in terms of managerial and cultural background, will be less attractive as alliance partners, given that the MNE will need to devote additional resources to understand and deal effectively with these cognitive-normative differences (Chan \& Makino, 
2007). When dealing with such distant partners, the MNE needs to commit additional resources to tailor their alliance capabilities (Kale \& Sigh, 2002) and bridge these differences (e.g., via new routines, work ethics, management training programs, upgrades of technological skills, etc.) for the alliance to succeed. As a result, coordination costs rise and impose greater uncertainty on both partners, which ex-ante make distant exploitative alliances seem riskier and costlier for the MNE (Gulati \& Singh, 1998). Furthermore, cultural and managerial distance leads to less cooperation and knowledge stickiness (Szulanski, 1996) impeding the proper flow of technical knowledge between partners. Familiarity with local norms and behaviors is tacit and requires additional efforts from the MNE to secure full cooperation from its partners and fluidize the flows of knowledge in the alliance via common organizational routines (Kostova, 1999). Finally, cognitive-normative differences reduce the absorptive capability of partners to transfer and implement successfully technology from the MNE, given their different ways (e.g., cognitive schemas and managerial dispositions) of sharing and using technical knowledge. Such normative-cognitive differences can impose significant constraints on firms' other activities and are a leading cause of alliance failures (Park \& Ungson, 1997; Mohr \& Spekman, 1994). Therefore, when engaging a distant cognitive (cultural) and normative (managerial) partner for exploitation, the MNE will face higher adjustment costs and greater uncertainty regarding the alliance. Thus:

H1: All else equal, when forming a technological alliance for exploitation, the MNE will prefer partners from closer normative and cognitive environments.

Furthermore, there are several rationales for which a MNE seeking international partners for an exploitative technological alliance will prefer firms from countries with similar or stronger regulatory environments (i.e., IPR). First, similar or stronger IPR regulations reduce MNE's appropriation concerns, thereby improving its ability to capture greater rents from the alliance 
(Gulati \& Singh, 1998) and benefit more from co-specialization of partners (Gimeno, 2004). Second, IPR facilitates the transfer of technology between partners by providing a global institutional framework for specialized markets for technologies, where firms can exploit their knowledge-intensive assets via licensing and other commercial tools (Arora et al., 2001). Finally, countries with similar or superior IPR regimes than that of the MNE will facilitate an efficient transfer of technology given their compatible IPR standards (Gans, Hsu \& Stern, 2008) and similar innovation capabilities (Krammer, 2009). In turn, these will increase MNE's opportunities for exploitation via technological alliances (Lavie \& Rosenkopf, 2006; Yamakawa et al., 2011; Peng et al., 2017).

In contrast, the MNE will be more wary of having partners from countries with weaker (i.e., less stringent) IPR regulations when forming an exploitation alliance, given the high appropriation concerns (Gulati \& Singh, 1998), reduced benefits from co-specialization (Gimeno, 2004), and difficulties in the transfer and commercialization of technologies (Branstetter et al., 2006; Krammer, 2009). Within an alliance, the scope of technical knowledge transferred to partnering firms is difficult to limit and monitor by the MNE, requiring costly alliance functions (Kale \& Singh, 2002) and raising concerns about free riders and technology leakages (Pisano, 1990; Krammer, 2016). These concerns are further inflated by weaker IPR regulations that facilitate technology leakages to domestic firms (Teece, 1986) and lower MNE ability to capture rents from exploitation of its current technological assets (Khoury \& Peng, 2011) ${ }^{1}$. Furthermore, worse IPR regulations than the home-country ones will interfere with MNE's ability to transfer technology to its partners. In such cases, lower IPR standards increase will MNE's perceived costs of sharing

\footnotetext{
${ }^{1}$ For example, in 2009 the US International Trade Commission has estimated that American firms in China lost around $\$ 48.2$ billion because of such IPR violations.
} 
technology by raising incompatibility issues in terms of dealing with intellectual property (Gans et al., 2008), and exposing them to threats of imitation or expropriation (Martinez-Noya \& GarciaCanal, 2011). As a result, firms from countries with worse regulatory environments compared to the MNE's home institutions will be less attractive as partners for a technological alliance (Contractor \& Ra, 2002). In sum, MNEs will seek to partner up in exploitation alliances with firms that are better or, at least, close in terms of regulatory provisions to their home environments. Based on all these arguments, I hypothesize that:

H2: All else equal, when forming a technological alliance for exploitation, the MNE will prefer partners from similar or stronger regulatory environments.

\section{The Other Edge of the Sword: Institutional Distance as an Advantage for Exploration}

I expect differences across institutional background to also affect partner selection for explorative alliances, though in different ways, and possibly at varying magnitudes. When searching for new knowledge through exploratory alliances, the MNE is implicitly committing itself to enter new domains and tap uncharted territories (Grant \& Baden-Fuller, 2004). While exploration is by definition a risky endeavor, pursuing partnerships in distant cognitive and normative backgrounds, it provides both the MNE with the potential to learn new routines and unique solutions which are often rooted in local and national contexts (Morosini, Shane, \& Singh, 1998). This diversity often stimulates managers to be more creative in terms of identifying and dealing with problems, thereby improving the efficiency and coherence of their decisions (GomezMejia \& Palich, 1997). Moreover, cognitive and normative heterogeneity is often associated with greater creativity and innovation (Cox and Blake, 1991), allowing firms to break certain organizational rigidities and develop new sources of knowledge (Barkema \& Vermeulen 1998; Stahl et al., 2010). Thus, diversity in terms of cultural backgrounds and managerial practices 
facilitates successful exploration endeavors, both in terms of innovative and international activities (Nathan \& Lee, 2013).

Furthermore, cognitive and normative differences will be positively related to partner selection for exploration simply because they are desirable when a firm is looking to import a different knowledge set. The specialized roles and routines of well-established MNEs tend to reduce the exploration opportunities of individuals in these firms (Sorensen, 2007), resulting in reliance on exploitative rather than explorative avenues to sustain performance (Fosstenløkken, Løwendahl, \& Revang, 2003). Given that both cognitive and normative differences are tacit, symmetric and dyadic (Zaheer, Schomaker \& Nachum, 2012), they meet well the challenges involved in absorbing a new, uncodified knowledge base. Technical knowledge, when exploratory, has a strong tacit component (Volkof, Strong \& Elmes, 2007), and therefore the more cognitively and normatively different partners will be, the more opportunities for exploration will exist within the alliance.

Finally, cognitive and normative distance between partners provides access to more heterogeneous resources that increase the overall absorptive capacity of the alliance. The successful assimilation of knowledge requires potential collaborators to poses good absorptive capabilities, e.g., R\&D activities, trained employees, knowledgeable managers, and efficient routines (Mowery et al., 2002). While people that have been raised in different environments tend to understand and evaluate differently operational problems, this distance is particularly useful in the case of exploration alliances (Noteboom et al., 2007), where learning and cross feeding are critical for overcoming the limitations of contextually localized searches (Rosenkopf \& Almeida, 2003). Thus, a cognitive-normative distant partner who brings into the alliance people who are differentially socialized, may be deemed especially useful in the context of an exploratory alliance. Subsequently, I posit that: 
H3: All else equal, when forming a technological alliance for exploration, the MNE will prefer partners from distant normative and cognitive environments.

The effects of regulatory distance on the selection of partners for exploration alliances can arguably be both positive and negative. On one hand, despite embracing ex-ante the uncertainty and risks associated with exploration, MNEs may still seek partners that are similar or better ranked in terms of IPR protection (Gulati, 1998). Thus, despite dealing with nascent technologies or fundamental knowledge that is of mostly tacit nature, the risks of leakage and loss of potential rents may still drive MNEs towards partners that are perceived to be closer in terms of regulatory prescriptions to minimize their appropriation concerns (Yang, Zheng, \& Zhao, 2014). Second, similar or stronger IPR standards adopted by prospective partners will reduce communication and development costs (Gans et al., 2008) typically associated with exploratory endeavors (e.g., a joint R\&D alliance). Having such IPR standards will allow specialists in the alliance to convert sophisticated specialized knowledge into directives, rules, and operating procedures that can be easily transferred between partners, and later on integrated into innovative products and services (Grant \& Baden-Fuller, 2004). Finally, having partners from closer regulatory environments will reduce the costs associated with the exploration portfolio of the MNE. As alliances become a primary vehicle for seeking new knowledge and technologies, many MNEs have developed large portfolios of partners that involve significant management costs and resources (Kale, Dyer, \& Singh, 2002). While firms with such dedicated "alliance functions" achieve better financial results and higher success rate for their alliances, the costs required to maintain these functions increases with heterogeneity of partners in a firm's portfolio. Hence, distant regulatory partners contribute directly to these costs, making them less attractive for exploration. Therefore: 
H4a: All else equal, when forming a technological alliance for exploration, the MNE will prefer partners from similar regulatory environments.

Alternatively, there are several grounds as for why regulatory differences may be helpful for MNEs seeking exploratory alliances. First, regulatory IPR differences may enable companies to leverage rules and regulations that are conducive to the development of new knowledge to the MNE, e.g., more liberal clinical trials for a pharmaceutical company in a country with more liberal/unregulated markets (Ghauri \& Rao, 2009). In this way, the opportunities for institutional arbitrage are greater (Gaur et al., 2007), and will benefit directly the search for knowledge by allowing the MNE more leeway in its exploration endeavors. Second, with respect to appropriation concerns, IPR gaps are less threatening to a firm in exploratory alliances because appropriability is less of a risk due to tacitness and fluidity of technological knowledge (Martinez-Noya \& GarciaCanal, 2011). Thus, distant partners in IPR do not translate automatically in lower ability of MNEs to capture rents from the potential technological gains of an exploratory alliance (Gimeno, 2004). Finally, given the nature of the sought benefits (e.g., tap into new sources of technologies, crossfeed across very different technological assets or portfolios) the knowledge transfer between partners will rely less on codified information (which falls directly under the regulations of IPR) in favor of tacit one, embedded in people and organizations (Volkof et al., 2007). As a result, greater IPR distance, regardless of its direction (i.e., positive or negative) can improve the attractiveness of a firm as an alliance partner for exploration. I therefore propose that:

H4b: All else equal, when forming a technological alliance for exploration, the MNE will prefer partners from more distant regulatory environments. 


\section{METHOD}

\section{Setting, sample and data}

To test these hypotheses, I use data on firms from the global tire industry. I focus on this industry for a number of reasons. First, over time, tire producers have formed numerous horizontal strategic alliances, providing a rich environment for studying partner selection. Second, this is a truly global industry, with firms in more than eighty countries, capturing greater institutional heterogeneity than the "usual suspects" in the alliance literature (i.e., high-tech sectors, confined to few developed nations). Finally, technology has always played an important role in this industry, especially at the top where significant R\&D efforts take place (see Table 1). An in-depth analysis of patenting activities by leading tire manufacturers supports this conjecture and suggests that these industry leaders maintain a broad spectrum of capabilities which helps them to integrate various streams of knowledge and technologies (Acha \& Brusoni, 2005). Moreover, technological capabilities have always played a critical role in the tire industry, shaping its historical evolution (Klepper \& Simons, 2000) and triggering new managerial responses (Sull, 2001) and international dynamics (Ito \& Rose, 2002).

\section{[Table 1 about here]}

The dataset employed in this study is comprised of data on all tire producers worldwide, manually collected from various issues of the European Rubber Journal (ERJ)2. Since partnering in a technological alliance is the dependent variable, I limit the sample to the years for which this information is available from these journals, namely 1985 to $2003^{3}$. To estimate partnering choices,

\footnotetext{
${ }^{2}$ These agreements have been cross-checked with alliance and joint-venture data from Thomson's SDC Platinum, however the ERJ data is much richer in documenting all technological interactions.

${ }^{3}$ After 2003 ERJ has stopped providing information on technological alliances.
} 
I construct a dataset of all possible dyads between firms in the industry over this period ${ }^{4}$. I then add to this data other firm characteristics (e.g., size, age and ownership) for both members of the dyad, also from ERJ.

In addition, I have manually collected data on tire-related patents assigned to these firms from Derwent Innovation Index (ISI Thomson), which has wide international coverage from multiple national patent offices. To assemble the patent data, I identify all patents assigned to tire producers and their affiliates that refer to tire products or processes. Using this information, I compute firm knowledge stocks in the "tires" domain, assuming an annual depreciation rate of 15 percent to discount their commercial and scientific relevance over time (Griliches, 1990). For firms that do not hold patents, I assume a null stock of technological knowledge. Analyzing the announcement of firms' alliances activities (ERJ), I identify whether an MNE (i.e., the focal firm) selects a partner in a dyad to form either an exploitative or an explorative technological alliance (coded as 1, and 0 otherwise). Following the text of these announcements, I identify the focal firm in a dyad to be the one that provides technology to its partner for exploitation, and respectively the firm taking the lead role in exploration alliances. For dyads with firms that do not form a technological alliance (i.e., no alliance announcement available), I consider the focal firm to be the one with the larger knowledge stock (i.e., granted patents) of the two. In case both firms have the same number of patents, the first firm listed in the dyad is arbitrarily considered the focal one. Lastly, I match the firm-level data with country characteristics such as gross domestic product

4 This excludes data from the first three years available (1986-1988), which are used to compute the "previous alliance experience" of partners variable (described in the subsection "Controls"). Thus, there are on average about 220 active firms in the tire industry each year, yielding around 385,000 potential undirected dyadic observations (220 times 219 , divided by 2 then multiplied by 16 years), before discarding missing observations. 
(GDP), GDP growth, geographic distance, institutional distances, colonial ties, and economic ties. Firms from countries where these data were not available have been dropped from the sample.

Dependent variable. Data on technological alliances between tire producers worldwide come from various issues of the Global Tire Report published in the European Rubber Journal (ERJ). Following prior work on technological alliances, I focus on the horizontal dimension of these agreements (Mowery et al., 2002; Lavie \& Rosenkopf, 2006; Hoang \& Rothaermel, 2010). This is consistent with theoretical arguments for clarity (Phelps, 2010) that favor horizontal alliances as a venue for technological exploitation and exploration, the unavailability of complete data on the population of firms in other industries (i.e., for vertical alliances), and the massive concentration of tire technologies within the industry with few outside players involved (Acha \& Brusoni, 2005). Hence, I examine the horizontal selection of international partners for technological alliances, either exploitative or explorative, as described in the original ERJ text.

Following the literature (Lavie \& Rosenkopft, 2006; Yamakawa et al., 2011), I capture both exploitative alliances, which involve "the use and development of things [i.e., technologies] already known" (March, 1991) and explorative alliances, which aim to create new-to- the-firm resources and competences in a desire the seize new strategic opportunities (Koza \& Lewin, 1998). I consider several types of exploitative alliances (i.e., long-term agreements involving joint marketing, service, OEM, licensing, supply and joint-production deals) in which the focal firm (i.e., the MNE) provides existing technologies to its partners in exchange for certain benefits (e.g., access to production facilities, services, etc.) and explorative alliances (i.e., R\&D alliances, R\&D jointventures, and long-term cross-licensing deals), which are commonly forged for explorative purposes such development of technology standards, solving of technical issues or technological 
collaboration $^{5}$. Thus, my dependent variable (Partner selection) is a binary dependent variable that equals 1 if the two firms in a dyad form a cross-border technological alliance in a year for exploitation (Exploit) and respectively, exploration (Explore) purposes, and zero otherwise. Multipartner alliances are treated as separate dyads for consistency. However, such agreements are extremely rare in the tire industry and tend to be exclusively geared towards exploration between top firms working on new technologies or seeking to promote new industry standards. The number of active alliances in the industry has steadily increased from 75 alliances in 1985 to 113 in 2003, with $81 \%$ forged for exploitative reasons. In terms of geographic distribution, I can see a concentration of technologies in the Triad countries (i.e., EU, Japan and the USA), which dictates pretty much the distribution of partners for exploration alliances (with the exception of several alliances with South Korean firms). In turn, the exploitative alliances are much more heterogeneous with partners, especially at the receiving end of these technologies, covering emerging markets from Asia, Africa and also Eastern Europe. Therefore, this heterogeneity justifies adopting a continuous measure of distance, as opposed to looking at average distance between blocks of countries (Beugelsdijk \& Mudambi, 2013). Finally, given that I consider all possible dyads between all firms in the industry, the number of instances in which the DVs take the value of 1 is extremely small ( $0.18 \%$ for exploitation and $0.02 \%$ for exploration) mandating corrections for rare-events, as described in the next section.

Independent variables. Following previous studies (Gaur et al., 2007; Estrin et al., 2009; He et al., 2013), my measure of the cognitive environment focuses on national culture differences as a determinant of alliance decisions (Steensma et al., 2000, Delerue \& Simon, 2009). I compute

\footnotetext{
${ }^{5}$ Concerning location of alliances, this is not an issue for all contractual agreements, distance being computed between the home countries of the two partners. However, in the case of JVs I do take into account specifically the location of the new entity based on the information provided by ERJ and use it for computing respective distances.
} 
a cultural distance index using Hofstede's five dimensions of culture (Hofstede et al., 2010) extracted from the website: http://www.geert-hofstede.nl. Together, these dimensions capture potential cognitive conflicts between alliance partners that stem from national differences in respect for authority [power distance], trust and job security [uncertainty avoidance], independence and the role of government [individualism], importance of family and work [masculinity], and future expectations [long-term orientation] (Shenkar, 2001).

My measure for the normative environment focuses on international management practices and reflects how inter-firm transactions are conducted across countries. Similar measures employing managerial attitudes and norms were used by other studies examining ownership (Xu et al., 2004) and MNE export strategies (He et al., 2013). Following them, I consider nine managerial norms $($ Cronbach's alpha $=0.91)$ retrieved from IMD's World Competitiveness Yearbook, which are relevant for partnering decisions in an international context: competence, credibility, efficiency of corporate boards, employee training, flexibility and adaptability, international experience, social responsibility and worker motivation ${ }^{6}$. Given the potential overlap between these variables, I perform exploratory factor analysis to determine the normative dimension (Table 2). Subsequently, variables with uniqueness above 0.6 are removed, and from the remaining seven items (alpha $=0.93)$ I derive a principal component $($ Eigenvalue $=4.53)$ for the latent variable that captures average managerial norms in a country ${ }^{7}$.

\section{[Table 2 about here]}

\footnotetext{
${ }^{6}$ For example, in terms of managerial competence, Israel, USA and Switzerland score the highest, while Croatia, Bulgaria and Peru are the lowest.

${ }^{7}$ Using command factortest in Stata I perform additional tests (Bartlett's sphericity, Kaiser-Meyer-Oklin sample adequacy) to assess the appropriateness of factor analysis, all with satisfactory results.
} 
Mirroring prior studies (e.g., Krammer, 2009; Cockburn et al., 2016) the technologyspecific regulatory elements are measured using global data on intellectual property rights (IPR). IPR data comes from Park's (2008) and covers five crucial aspects of IP: extent of coverage (patentability of different products), membership in international agreements (e.g., TRIPS, international patent conventions), enforcement options (e.g., injunctions, infringements), restrictions on patent rights, and duration of protection. This index is computed as a weighted average of these five dimensions and covers 122 countries over the period 1960-2005 ${ }^{8}$ The frequency of observations is every five years, and values have been linearly interpolated under the assumption that these laws do not vary significantly within this interval.

Data on cognitive and normative institutions are used to compute dyadic (symmetric) distances between two countries using the Mahalanobis formula (Berry et al., 2010)9 ${ }^{9}$. Regulatory distance between countries is computed as a simple difference between the IPR score of the focal firm (i.e., the MNE) and its prospective partner in a dyad. This distance is asymmetric and in this case direction counts, hence, the partner can be "stronger" (positive value) or "weaker" (negative value) vis-à-vis the MNE (Zaheer et al., 2012). Both regulatory and normative distances vary over time to accommodate potential institutional dynamics (Frantianni \& Oh, 2009). Given that I have multiple reference countries when computing these distance measures within a dyad, I do not include level effects (Beugelsdijk, Kostova, \& Roth, 2017).

Controls. I include several other variables that are closely related to alliance partner selection. Firm size and age (experience) are two important determinants of its strategy (Kale \& Singh, 2009). Firm size differential is computed using the production capacity of firms within a

\footnotetext{
${ }^{8}$ USA, Netherlands and Japan have the strongest IPR provisions, while Burma, Angola and Guyana have the weakest.

${ }^{9}$ The correlation between the Euclidian distance and the Mahalanobis one is fairly high (0.69 for cognitive and 0.70 for normative) and statistically significant at $1 \%$, suggesting that either one can be successfully employed in this case.
} 
dyad, while firms' age differential is determined using the opening year of their first plants. To capture the strategic interdependence between firms (Gulati, 1995b) in terms of technologies, I calculate the firm knowledge differential using firms' annual patent stocks computed from Derwent Innovation Index with a $15 \%$ annual depreciation rate (Griliches, 1990). To control for benefits from prior or current equity links between firms in a dyad, several dummies are included for cases in which partners are majority, minority ownerships or joint-venture projects. Another important motivation for international exploitative alliances is to access new, dynamic markets (Glaister, 1996). At the country level, market size differential and market growth differential are computed using GDP figures for both countries involved, extracted from the World Penn Tables 7.1. Furthermore, a common proxy for external uncertainty in international business is geographic distance (Berry et al., 2010). To account for this, I use a more refined measure of geographic distance (weighted by population) between countries obtained from the CEPII database. This distance corrects for agglomeration effects (e.g., economic and population terms) within countries that might bias upwards the coefficient of a simple geodesic distance. To control for "border effects" known to impact economic exchanges between countries (Schulze \& Wolf, 2009), I employ a dummy for geographic contiguity (CEPII). Finally, a critical ingredient for alliances is the existence of dedicated capabilities (Kale \& Singh, 2002). I proxy these capabilities using previous alliance experience (calculated as the cumulative number of alliances for both firms in a dyad in the 3 previous years) and a partner-specific experience dummy (prior interactions), which captures whether the two firms in a dyad have previously engaged in other alliances.

[Table 3 about here] 


\section{Estimation technique}

The unit of analysis is the dyad, and I consider all undirected pairs of firms in the tire industry for which data on all explanatory and control variables is available. For consistency, I use the listwise deletion method to deal with missing observations and preserve the same sample across different empirical specifications. After eliminating all missing observations for these variables, we are left with a sample of 204,366 dyadic observations. Table 3 presents descriptive statistics for all variables. Analyzing firm dyads increases significantly the dimension of the dataset, but also introduces an additional problem: given the very low (only 0.18 percent for exploitation and 0.02 for exploration) number of $1 \mathrm{~s}$ in the data, running a regular probit or logit estimation will underestimate the probability of selecting a partner for both types of technological alliances. Thus, I employ a rare-event logit model that relies on maximum likelihood estimation and generates coefficients with lower mean square errors than the standard model by correcting for rare-events (King \& Zeng, 2001). Moreover, since the data contain all possible dyads among these firms across time, it faces potential problems of unobserved heterogeneity and autocorrelation. To deal with this, I follow Wang \& Zajac (2007) and use robust standard errors clustered on each dyad in all estimations. Time dummies are added to all estimations.

A second major concern regarding the partner selection process in alliances refers to endogeneity. Many studies have investigated partner selection by estimating regressions using a sample of observed alliances, under the assumption that the selection process is independent of the firm characteristics. However, it is likely that these characteristics affect both the decision to engage in a technological alliance and that of whom to partner with. Thus, the former is a result of a firm's own characteristics (e.g., range of available technologies, market potential, experience etc.), while the latter depends on the characteristics of both prospective partners. To deal with these endogeneity concerns I use a two-stage correction procedure (Heckman, 1979). Using probit 
analysis, the first stage estimates the probability of a firm to engage in technological alliance as a function of its size, age, patent stocks, home market size and dynamics. In this first stage the unit of analysis is the firm. In the second stage, using a rare-event logit estimator, I analyze whether firms choose partners systematically based on different firm and country specifics. To correct for the self-selection issue, I include an Inverse Mills Ratio derived from the probit regression of the first stage. In the second stage the unit of analysis is the dyad. Since I use a two-stage selection model, the first-stage variables (instruments), which are firm-specific, do not appear in the second stage regressions.

\section{[Table 4 about here]}

Table 4 presents the pairwise correlation matrix. Most correlations are within acceptable limits, indicating that there are no severe collinearity issues to affect these estimations.

\section{RESULTS}

Table 5 reports the effects of institutional distance on selection of international partners for exploitation and exploration. In terms of significant effects of control variables, with respect to exploitation, most of these effects pertain to ownership strategies (with majority and minority holdings trumping the effect of JVs), differentials in terms of market growth potential, and alliancespecific factors such as previous experience or interactions between two partners, in addition to the correction factor for self-selection (i.e., the Inverse Mills ratio). For exploration alliances, in addition to these factors, firm knowledge, age and size differentials are also detrimental as well as differences in terms of market size. Interestingly, and as expected from a diversity perspective, geographical distance has a positive effect on partner selection.

[Table 5 about here] 
Going to the hypotheses now, the results support $\mathrm{H} 1$ and $\mathrm{H} 2$, namely that, ceteris paribus, institutional distance reduces a partner's appeal for exploitation alliances. Thus, cognitive, normative and regulatory distance have all negative and highly significant coefficients suggesting that MNEs prefer partners from similar institutional environments for exploitation. In turn, institutional distance appears to be conductive of partnering for exploration, thus supporting $\mathrm{H} 3$ and $\mathrm{H} 4 \mathrm{~b}$. Both cognitive and regulatory distance exhibit positive and highly significant coefficients in these regressions ${ }^{10}$. The exception is normative (managerial) distance, which is negatively associated with partner selection for exploration alliances. Lastly, it is worthwhile mentioning that the effects of all three institutional distances are additive and robust, at least for exploitation (Model 5), as postulated by the theory (Kostova, 1999).

Considering the nonlinear nature of the chosen estimator, the above coefficients provide limited information above the economic magnitude of these effects. Subsequent analyses carried out have explored this issue in more depth by examining the marginal effects for my main variables of interest and contrasting them with those of main controls. The full batch of these results is available upon request. For this exercise I have used the final results for exploitation and exploration alliances reported in Models 5 and respectively 10. Overall, these results are in line with my main findings and in terms of magnitudes comparable with other studies that have used large dyadic settings (Vasudeva, Spencer, \& Teegen, 2013). Thus, all else equal, for an average firm when considering prospective partners for exploitation, moving from lower cognitive distance (e.g., USA-Guatemala), to a medium one (e.g., USA-South Africa) or a larger one (e.g., USA-China) can reduce the probability of selection by up to 2.88 percent. Similarly, the propensity to select distant

\footnotetext{
${ }^{10}$ To test H4b in Model 9 I use an absolute value of IPR distance as opposed to a simple difference. In this way, a positive coefficient would support $\mathrm{H} 4 \mathrm{~b}$, while a negative one would support H4a.
} 
partners in terms of normative and regulatory institutional backgrounds decreases with distance by up to 0.38 percent in the case of very distant regulatory backgrounds (e.g., USA-Angola) and 0.18 percent for very distant normative ones (e.g., Malaysia-Russia), all else equal. By contrast, for selection for exploration alliances, more distant cognitive partners (e.g., USA-Japan) and less distant normative ones (e.g., France-Germany) will be more attractive for selection, but the magnitude of these effects on selection is slightly smaller (reaching up to 2.16 percent for cognitive and 0.07 percent for normative in the case of very distant partners). Overall, these effects provide a more intuitive picture regarding the relevance of institutional distance for selection of partners in both exploration and exploitation alliances, suggesting that while institutional differences are important and on-par with other firm-specific explanations, other factors (such as previous links between firms or equity links between prospective partners) tend to prevail in terms of magnitudes.

\section{Robustness checks}

I test the robustness of these results by performing several other analyses. First, I include several other cross-country distances (i.e., connectedness, knowledge, economic, and political) proposed by Berry et al. (2010). Despite a significant sample size reduction, the coefficients of the institutional distances considered remain negative and highly statistically significant, except for normative distance, re-enforcing my prior conclusions. Of all these additional distance measures considered, only economic distance is statistically significant, implying that partner selection is generally negatively affected by differences in the macroeconomic conditions surrounding prospective partners.

Second, alliance experience is commonly computed in the literature using the number of alliances a firm forms in the past 5 or 10 years. Given the time coverage of this dataset (19 years) and the strong correlation across time between the number of alliances firms form in a year, I have 
opted for a shorter time window of three years. However, as a robustness check I have re-run all regressions using more restrictive windows of 5 and 10 years, respectively, for computing the alliance experience variable. As expected, the magnitude of these coefficients is smaller (e.g., on average, 0.44 for 5 -year and 0.34 for 10 -year window), but the main results hold despite the severe reductions in sample size (counting around 115,000 and respectively 64,000 observations for the 5- and 10-year window). Results of these robustness checks are not reported here due to space constraints but are available upon request.

Finally, an alternative explanation for the impact of institutional differences on partner selection is that these differences could have a discrete rather than a continuous effect. To test this

possibility, I have used the cultural clusters developed by Ronen \& Shenkar (2013) to compute an additional control variable (samecultcluster) which is a dummy that equals 1 when the two countries in a dyad belong to the same cultural cluster, and 0 otherwise. The results of this analysis suggest that sharing the same cultural cluster does not make a difference when it comes to neither exploitation or exploration alliances. The sign of samecultcluster remains negative and not statistically significant while the main explanatory variables retain similar, signs, magnitudes and statistical significance.

\section{DISCUSSION AND CONCLUSIONS}

Although technological alliances have become a popular tool for securing competitive advantage (Anand \& Khanna, 2000), their success hinges heavily on the selection process (Shah \& Swaminathan, 2008). In an international context, this process involves vetting of potential partners for institutionally-related differences that may affect the performance of the alliance (Hitt et al., 2004; Sarala et al., 2014). This study sheds light on the role played by institutional differences in the partner selection process by employing a set of theoretical lenses to disentangle these complex 
effects. The first such lens, which seeks to infuse strategic objectives into the partner selection process, derives from the nature of objective/s of the alliance regarding knowledge seeking and learning, and is reflected by the exploration and exploitation tension (Koza \& Levin, 1998; Lavie \& Rosenkopf, 2006). The second lens, which aims to capture the complexity of the international environment, is Scott's (1995) distinction among normative, cognitive, and regulative pillars of institutions (Xu \& Shenkar, 2002; Eden \& Miller, 2004) and the distance between countries across these institutional dimensions (Kostova, 1999) as a criterion for partner selection.

Although generated by disparate theoretical currents, these lenses are of complementary nature, forming a comprehensive ensemble with which to understand cross-border alliances, and in this case, the selection of new partners. One combination of the above lenses, which I explore in this paper, is between specific institutional pillars and the strategic logic of exploration versus exploitation. The results confirm the core theoretical conjectures of the paper, namely that MNEs seek partners from closer institutional backgrounds for exploitative endeavors, driven by efficiency and appropriability concerns for their technological assets. In turn, the selection of alliance partners for exploration is positively related to institutional distance across cognitive and regulatory elements, as the opportunities for technological learning (Teece, 1986) and institutional arbitrage (Gaur et al., 2007) are greater. Overall, these contrasting forces provide a balanced and realistic view of the institutional gaps between alliance partners, confirming their complex role in the selection process.

Another insight from this work is that the effects of institutions on firm strategies varies across different types of institutions considered. I find that distant cognitive and regulatory partners are more appealing for exploration alliances given the need to diversify and complement each other's knowledge (Schildt et al., 2005). Nevertheless, differences in terms of normative (managerial) values act as a barrier even for exploration alliances, suggesting that the greater transactions costs and uncertainty associated with these differences deter firms from pursuing such 
partnerships (Olie, 1994; Zhao, 2006). Together, these findings provide a more fine-grained view of the effects of institutional distance, and signal the importance of distinguishing between different institutional pillars, as their effects might not be uniform in relation to a given firm strategy (Yamakawa et al., 2011).

Last but not least, my results support the idea to view institutional differences as enacted by the underlying strategic logic of an alliance, which in this paper is the nature of the knowledge search, drawing a clear distinction between exploration and exploitation objectives (March, 1991). My theoretical arguments support the antipodal institutional effects in relation to knowledge seeking, providing an explanation as to why certain national differences may appear to be conducive to certain alliance activities, while inhibiting others (Parkhe, 1991). This finding is at odds with the dual strategic role of alliances in accessing and acquiring external knowledge, and its subsequent effect on improving its integration and utilization in the production process (Grant \& Baden-Fuller, 2004).

On a theoretical level, this study advocates a convergence between TCE arguments, which emphasize complementarity and interdependence as prime rationales for partner selection (Williamson, 1975; Hennart, 1988), and institutional theory, which views institutions as motivating and shaping firm behavior (Di Maggio \& Powell, 1983; Scott, 2001). A core contribution lies in theorizing how different institutional pillars affect partner selection for alliances, thus complementing prior findings on the role that firm-specifics (Annand \& Khanna, 2000; Rothaermel \& Boeker, 2008) and national idiosyncracies (Hitt et al., 2000; Hitt et al., 2004) play in this selection process. Moreover, the mechanisms through which different institutions affect the selection process appear antipodal, contingent on the learning objective -exploration or exploitation- of the alliance (March, 1991), resulting in a "double-edged sword" effect of institutions on firm strategies. Finally, my findings suggest that cognitive and normative differences tend to trump in magnitude the effect of regulatory gaps between prospective partners, 
consistent with prior, albeit qualitative evidence (Olie, 1994). Thus, regulatory regimes that have a key position in the transaction costs argument and are a vital component in the broader economic view of "formal institutions" need to be supplemented by informal institutions, with each fulfilling a different role (North 1990; Vasudeva et al., 2013; Krammer, 2017). This resonates also with the idea of MNEs internalizing regulatory deficiencies abroad via dedicated internal mechanisms designed to reduce appropriation concerns and other negative externalities (Zhao, 2006).

\section{Policy and Managerial Relevance}

These findings draw the attention of policy makers and managers to the importance of cognitive (cultural) and normative (managerial) differences that lead to divergent behaviors (Kelly et al., 2000) that may affect the success of an alliance (Delerue \& Simon, 2009). In particular, large cognitive and normative differences are notoriously difficult to overcome due to their tacit nature and centennial inertia (Hofstede et al., 2010), and this burden will largely fall on management in charge of these inter-firm relationships. Consequently, distant normative and cognitive partners deserve more consideration from managers when considering an alliance. At the same time, weaker regulatory (i.e., IPR) environments of a prospective partner vis-a-vis the home country of the MNE will reduce its appeal as an alliance partner, prompting the significant role policy makers can play in facilitating these technological transfers across borders via alliances by improving IPR standards and their enforcement (Khoury \& Peng, 2011). As a result, host-country managers should lobby policy makers for reforms or develop alternative safeguarding mechanisms to attract MNEs as technological partners. In exploration alliances, greater institutional distance across cognitive and regulatory elements is associated with more appeal for exploration alliances, where firms seek to complement each other in terms of knowledge and technologies (Koza \& Levin, 1998); however, this does not negate the value of a developing a sharing platform to enable effective cooperation and knowledge dissemination. Thus, firms must develop and preserve a certain degree of strategic 
agility when seeking exploration via technological alliances (Weber \& Tarba, 2014). Complementarily, the development of managerial skills and adherence to international standards can help in that, and should become a priority at the level of both nations (i.e., via educational curricula) and firms (i.e., via in-house training).

\section{Limitations and Suggestions for Future Research}

This study has several limitations that could serve as starting points for future research. First, whereas my theoretical predictions do not rely on any idiosyncratic features of the industry, and therefore are generalizable to other empirical settings, the empirical testing relies on one industry. Thus, future studies in this area may want to test whether these antipodal effects of distance hold across different industrial contexts with significant international coverage to ensure sufficient institutional heterogeneity. While these effects could be valid across different industries, other idiosyncratic characteristics may result in different magnitudes and rankings for the MNEs in terms of priorities and institutional barriers, as suggested by scant work in this area (Olie, 1994).

Second, I have focused exclusively on the technological and horizontal (i.e., withinindustry) dimensions of alliances, given the concentration of technology production and assets (i.e., patents) among top tire producers (Acha \& Brusoni, 2005) and the special feature of the tire industry, which has been historically dominated by horizontal rather than vertical technological exchanges (ERJ, various issues). However, firms in other contexts (e.g., high-tech industries such as pharmaceuticals or biotechnology), characterized by complex and dynamic technological environments, often adopt a more mixed partnering strategy, which includes both horizontal and vertical alliances for exploration and exploitation (Rothaermel \& Boeker, 2008). As such, an interesting extension of this work would be to incorporate, particularly in other industry-settings that fit better this description, the non-technological and vertical types of alliances formed by focal 
firms of the industry. This would allow for richer theorizing of institutional and learning rationales across a wider array of alliances.

Third, the nature of the data (i.e., secondary) and empirical setting (i.e., mature, low-tech, concentrated industry) limits our ability to control for compatibility, commitment, and complementarity of partners to differences in terms of age, size, and knowledge stocks. Ideally, a combination of primary and secondary data could further refine our understanding of how and when firm specifics trump institutional contingencies for selection of partners. Similarly, future studies may test specifically the effects of international experience at the level of the firm (e.g., prior presence, or international sales in these markets) or even deeper levels of analysis (e.g., executive international experience, cultural breadth of the board etc.) which are not available for many firms in this industry, in particular those from emerging markets. Such research will extend the ramifications of the present study by reaching into other key domains of alliance research.

Finally, despite its popularity in the international business community, inconsistent and often contradictory findings regarding the effect of distance on firm international activities have raised important operational and methodological challenges (Zaheer et al., 2012; Ambos \& Håkanson, 2014). The focal objective of this study was to theoretically explain and test empirically the antipodal effects of institutional distance on selection of partners. To this end, I have employed different operationalization choices for the main independent variables, in line with previous studies (e.g., Gaur et al., 2007; He et al., 2013). Nevertheless, these choices rely on several critical assumptions that need further examination. For instance, while I specifically allow for asymmetric effects in the case of regulatory (IPR) distance, I have treated cognitive and normative differences as symmetric under the assumption that the magnitude (but not the direction) of these differences matters for the process of alliance partner selection. In turn, recent contributions in this area suggest that asymmetry could be important, particularly for certain firm strategies and cultural dimensions (Beugelsdijk et al., 2017; Huang, Zhu, \& Brass, 2017) and for identifying causal mechanisms 
behind these relationships (Håkanson et al., 2016). Although in the particular context of the tire industry, most exploitation alliances do not exhibit reversals within the dyad in terms of origin of focal firms, and exploration alliances work on the assumption that larger distance would be beneficial, the magnitude of effects for distances may differ once asymmetry is specifically captured. Hence future research may want to explore this issue through primary data collection of institutional differences across countries, as perceived by firm managers. These endeavors would allow us to closer examine whether such critical assumptions of distance metrics (e.g., symmetry) are met in the context of large samples and particular strategies (e.g., technology sharing via alliances; M\&As; outsourcing; FDI, etc.). 


\section{REFERENCES}

Acha, V. and Brusoni, S., 2005. "Complexity and industrial evolution: new insights from an old industry" In: Finch, J. and O. Magali, Eds. Complexity and the economy. Edward Elgar, Cheltenham, UK.

Ahlstrom, D., Levitas, E., Hitt, M. A., Dacin, M. T., \& Zhu, H., 2014. The three faces of China: Strategic alliance partner selection in three ethnic Chinese economies. Journal of World Business, 49, 572585.

Ambos, B., \& Håkanson, L. 2014. The concept of distance in international management research. Journal of International Management, 20(1), 1-7.

Anand, B. N., \& T. Khanna. 2000. "Do Firms Learn to Create Value? The Case of Alliances." Strategic Management Journal 21 (3): 295-315.

Arora, A., A. Fosfuri, \& A. Gambardella. 2001. "Markets for Technology and Their Implications for Corporate Strategy." Industrial and Corporate Change 10 (2): $419-451$.

Grant, R. M., \& Baden-Fuller, C. (2004). A knowledge accessing theory of strategic alliances. Journal of Management Studies, 41(1), 61-84.

Bae, J.H., \& R. Salomon. 2010. "Institutional Distance in International Business Research." The Past, Present and Future of International Business \& Management (Advances in International Management, Volume 23), Emerald Group Publishing Limited 23: 327-349.

Barkema, H.G., Shenkar, O., Vermeulen, F., \& Bell, J.H.J. 1997. Working abroad, working with others, Academy of Management Journal, 40, 2, 426-442

Bekkers, R., Duysters, G., \& Verspagen, B. (2002). Intellectual property rights, strategic technology agreements and market structure: The case of GSM. Research policy, 31(7), 1141-1161.

Beckman, C.M., P.R. Haunschild, \& D.J. Phillips. 2004. "Friends or Strangers? Firm-Specific Uncertainty, Market Uncertainty, and Network Partner Selection.” Organization Science 15 (3): 259-275.

Belderbos, R., Jacob, J., \& Lokshin, B. (2018). CVC Investments and technological performance: Geographic diversity and the interplay with technology alliances. Journal of Business Venturing 33 (1): 20-34.

Berry, H., M. F. Guillen, \& N. Zhou. 2010. "An Institutional Approach to Cross-national Distance." Journal of International Business Studies 41 (9): 1460-1480.

Beugelsdijk, S., \& Mudambi, R. 2013. MNEs as border-crossing multi-location enterprises: The role of discontinuities in geographic space. Journal of International Business Studies 44(5): 413-426.

Beugelsdijk, S., Kostova, T., \& Roth, K. (2017). An overview of Hofstede-inspired country-level culture research in international business since 2006. Journal of International Business Studies, 48(1), 30-47.

Branstetter, L. G, R. Fisman, \& C. F Foley. 2006. "Do Stronger Intellectual Property Rights Increase International Technology Transfer? Empirical Evidence from US Firm-Level Panel Data." Quarterly Journal of Economics 121 (1): 321-349.

Brouthers, K.D. \& L.E. Brouthers, 2000. Acquisition or greenfield start-up? Institutional, cultural and transaction cost influences. Strategic Management Journal 21: 89-97

Burgers, W.P., C. W. L. Hill, \& W.C. Kim. 1993. "A Theory of Global Strategic Alliances: The Case of the Global Auto Industry." Strategic Management Journal 14 (6): 419-432.

Chan, C.M., \& S. Makino. 2007. "Legitimacy and Multi-level Institutional Environments: Implications for Foreign Subsidiary Ownership Structure.” Journal of International Business Studies 38(4): 621-638.

Chand, M. \& Katou, A. A. (2012). Strategic determinants for the selection of partner alliances in the Indian tour operator industry: A cross-national study. Journal of World Business, 47, 167-177. 
Cockburn, I. M., Lanjouw, J. O., \& Schankerman, M. (2016). Patents and the global diffusion of new drugs. American Economic Review, 106(1), 136-64.

Contractor, F.J., \& W. Ra. 2002. "How Knowledge Attributes Influence Alliance Governance Choices:: A Theory Development Note." Journal of International Management 8 (1): 11-27.

Dacin, M.T., M.A. Hitt, \& E. Levitas. 1997. "Selecting Partners for Successful International Alliances: Examination of U.S. and Korean Firms." Journal of World Business 32 (1): 3-16.

Dacin, M. T., M.J. Ventresca, \& B.D. Beal. 1999. "The Embeddedness of Organizations: Dialogue \& Directions." Journal of Management 25 (3): 317-356.

Delerue, H., \& E. Simon. 2009. "National Cultural Values and the Perceived Relational Risks in Biotechnology Alliance Relationships.” International Business Review 18 (1): 14-25.

Delios A, \& Beamish P. 1999. Ownership strategy of Japanese firms: transactional, institutional, and experience influences. Strategic Management Journal 20: 915-933.

DiMaggio, P.J., \& W.W. Powell. 1983. "The Iron Cage Revisited: Institutional Isomorphism and Collective Rationality in Organizational Fields." American Sociological Review 48 (2)

Dong, L., \& K.W. Glaister. 2006. "Motives and Partner Selection Criteria in International Strategic Alliances: Perspectives of Chinese Firms." International Business Review 15 (6): 577-600.

Eden, L., \& S. R Miller. 2004. "Distance Matters: Liability of Foreignness, Institutional Distance and Ownership Strategy.” Advances in International Management 16: 187-221.

Estrin, S., D. Baghdasaryan, \& K.E. Meyer. 2009. "The Impact of Institutional and Human Resource Distance on International Entry Strategies.” Journal of Management Studies 46 (7): 1171-1196.

Gans, J.S., D.H. Hsu, \& S. Stern. 2008. "The Impact of Uncertain Intellectual Property Rights on the Market for Ideas : Evidence from Patent Grant Delays."Management Science 54 (5): 982-997.

García-Canal, E., A. Valdés-Llaneza, \& P. Sánchez-Lorda. 2008. "Technological Flows and Choice of Joint Ventures in Technology Alliances.” Research Policy 37 (1): 97-114.

Gaur, A.S., \& J.W. Lu. 2007. "Ownership Strategies and Survival of Foreign Subsidiaries: Impacts of Institutional Distance and Experience.” Journal of Management 33 (1): 84-110.

Gaur, A.S., A. Delios, \& K. Singh. 2007. "Institutional Environments, Staffing Strategies, and Subsidiary Performance.” Journal of Management 33 (4): 611-636.

Ghauri, P. N., \& Rao, P. M., 2009. Intellectual property, pharmaceutical MNEs and the developing world. Journal of World Business, 44(2), 206-215.

Geringer, J. M. 1991. "Strategic Determinants of Partner Selection Criteria in International Joint Ventures." Journal of International Business Studies 22 (1): 41-62

Gimeno J., 2004. Competition within and between networks: the contingent effect of competitive embeddedness on alliance formation. Academy of Management Journal 47(6): 820-842.

Glaister, K.W. 1996. "UK-Western European Strategic Alliances - Motives and Selection Criteria." Journal of Euromarketing 5 (4): 5.

Griliches, Z., 1990. Patent Statistics as Economic Indicators: A Survey. Journal of Economic Literature 28 (4): 1661-1707.

Gulati, R. 1995a. "Does Familiarity Breed Trust? The Implications of Repeated Ties for Contractual Choice in Alliances." Academy of Management Journal: 85-112.

Gulati, R. 1995b. "Social Structure and Alliance Formation Patterns: A longitudinal Analysis". Administrative Science Quarterly 40 (4): 619-652.

Gulati, R., \& H. Singh. 1998. "The Architecture of Cooperation: Managing Coordination Costs and Appropriation Concerns in Strategic Alliances.” Adm Science Quarterly 43 (4): 781-814.

Hagedoorn, J., \& Hesen, G. (2007). Contract law and the governance of inter-firm technology partnerships-An analysis of different modes of partnering and their contractual implications. Journal of Management Studies, 44(3), 342-366.

Håkanson, L., Ambos, B., Schuster, A., \& Leicht-Deobald, U. 2016. The psychology of psychic distance: Antecedents of asymmetric perceptions. Journal of World Business, 51(2), 308-318. 
He, X., K.D. Brouthers, \& I. Filatotchev. 2013. "Resource-Based and Institutional Perspectives on Export Channel Selection and Export Performance." Journal of Management 39(1):27-47.

Heckman, J. 1979. "Sample Selection Bias as a Specification Error." Econometrica 47: 153-161.

Henisz, W., \& A. Swaminathan. 2008. "Institutions and International Business." Journal of International Business Studies 39 (4): 537-539.

Hennart, J.F. 1988. A transaction costs theory of equity joint ventures. Strategic Management Journal, 9, 361-374.

Hitt, M. A, M. T Dacin, E. Levitas, J. L Arregle, \& A. Borza. 2000. "Partner Selection in Emerging and Developed Market Contexts: Resource-based and Organizational Learning Perspectives." The Academy of Management Journal 43 (3): 449-467.

Hitt, M.A, H. Li, \& W.J. Worthington. 2005. "Emerging Markets as Learning Laboratories: Learning Behaviors of Local Firms and Foreign Entrants in Different Institutional Contexts." Management and Organization Review 1 (3): 353-380.

Hitt, M.A., D. Ahlstrom, M.T.Dacin, E. Levitas, \& L. Svobodina. 2004. "The Institutional Effects on Strategic Alliance Partner Selection in Transition Economies: China Vs. Russia." Organization Science 15 (2): 173-185.

Hoang, H., \& F. T Rothaermel. 2010. "Leveraging Internal and External Experience: Explora-tion, Exploitation, and R\&D Project Performance.” Strategic Management Journal 31 (7).

Hofstede, G., G. J. Hofstede and M. Minkov. Cultures and Organizations: Software of the Mind, 3rd ed. New York: McGraw-Hill. 2010.

Huang, Z., Zhu, H. S., \& Brass, D. J. (2017). Cross-border acquisitions and the asymmetric effect of power distance value difference on long-term post-acquisition performance. Strategic Management Journal, 38(4), 972-991.

Ireland, R.D., M.A Hitt, and D.Vaidyanath. 2002. "Alliance Management as a Source of Competitive Advantage." Journal of Management 28 (3): 413-446.

Ito, K., and E.L. Rose. 2002. "Foreign Direct Investment Location Strategies in the Tire Industry." Journal of International Business Studies 33 (3): 593-602.

Kale, P. J. H Dyer, and H. Singh. 2002. Alliance Capability, Stock Market Response, and Long-term Alliance Success: The Role of the Alliance Function. Strategic Management Journal 23: 747-67.

Kale P., and Singh H. 2009. Managing Strategic Alliances: What Do We Know Now, and Where Do We Go From Here?" The Academy of Management Perspectives 23(3): 45-62.

Kelly, M.J., J.L. Schaan, and H. Joncas. 2002. "Managing Alliance Relationships: Key Challenges in the Early Stages of Collaboration." R\&D Management 32 (1): 11-22.

Khoury, T.A., and M.W. Peng. 2011. "Does Institutional Reform of Intellectual Property Rights Lead to More Inbound FDI? Evidence from Latin America and the Caribbean." Journal of World Business 46 (3): 337-345.

Klepper, S., and K.L. Simons. 2000. "The Making of an Oligopoly: Firm Survival and Technological Change in the Evolution of the U.S. Tire Industry." Journal of Political Economy 108(4): 728-760.

King, G., and L. Zeng. 2001. "Logistic Regression in Rare Events Data.” Political Analysis 9 (2): 137 163.

Kostova, T. 1999. "Transnational Transfer of Strategic Organizational Practices: A Contextual Perspective." Academy of Management Review: 308-324.

Kostova, T., and Zaheer S., 1999. "Organizational Legitimacy Under Conditions of Complexity: The Case of the Multinational Enterprise." Academy of Management Review 24 (1): 64-81.

Koza M.P., A. Levin, 1998. The Co-evolution of strategic alliances. Org Science 9(3): 255-264

Krammer, S.M.S., 2009. Drivers of national innovation in transition: Evidence from a panel of Eastern European countries. Research Policy, 38(5), 845-860. 
Krammer, S.M.S., 2016. The role of diversification profiles and dyadic characteristics in the formation of technological alliances: Differences between exploitation and exploration in a low-tech industry. Research Policy, 45(2), 517-532.

Krammer, S.M.S., 2017. Greasing the wheels of change: bribery, institutions, and new product introductions in emerging markets. Journal of Management, 0149206317736588.

Krammer, S. M. S., Strange, R., \& Lashitew, A., 2018. The export performance of emerging economy firms: The influence of firm capabilities and institutional environments. International Business Review, 27(1), 218-230.

La Porta, R., F. Lopez-de-Silanes, and A. Shleifer. 2008. "The Economic Consequences of Legal Origins.” Journal of Economic Literature 46 (2): 285-332.

Lavie, D., and L. Rosenkopf. 2006. "Balancing Exploration and Exploitation in Alliance Formation." Academy of Management Journal 49 (4): 797.

Levinthal, D.A., ans J.G. March. 1993. The myopia of learning. Strategic Management Journal, 14, 95-112.

Lu, J.W. 2002. "Intra- and Inter-organizational Imitative Behavior: Institutional Influences on Japanese Firms’ Entry Mode Choice.” Journal of International Business Studies 33(1): 19-37.

March, J.G. 1991. "Exploration and Exploitation in Organizational Learning." Organization Science 2 (1): 71-87.

Martinez-Noya, A., \& E. García-Canal, 2011. "Technological Capabilities and the Decision to Outsource/outsource Offshore R\&D Services." International Business Review 20 (3):264-277.

Meyer, K.E., S. Estrin, S.K. Bhaumik, \& M.W. Peng. 2009. "Institutions, Resources, and Entry Strategies in Emerging Economies.” Strategic Management Journal 30 (1): 61-80.

Michailova, S., and K. Hutchings. 2006. "National Cultural Influences on Knowledge Sharing: A Comparison of China and Russia." Journal of Management Studies 43 (3): 383-405.

Mohr, J., and R. Spekman. 1994. "Characteristics of Partnership Success: Partnership Attributes, Communication Behavior, and Conflict Resolution Techniques." Strategic Management Journal 15 (2): 135-152.

Mowery, D.C., J.E. Oxley, and B.S. Silverman. 2002. The Two Faces of Partner-specific Absorptive Capacity: Learning and Cospecialization in Strategic Alliances. Elsevier: Oxford.

Nathan, M., and Lee, N. 2013. Cultural Diversity, Innovation, and Entrepreneurship: Firm-level Evidence from London. Economic Geography, 89(4), 367-394.

North, D. C. 1990. Institutions, Institutional Change and Economic Performance. Cambridge University Press.

Olie, R. 1994. "Shades of Culture and Institutions-in International Mergers." Organization Studies 15 (3): 381-405.

Oxley, J. E. 1999. "Institutional Environment and the Mechanisms of Governance: The Impact of Intellectual Property Protection on the Structure of Inter-firm Alliances." Journal of Economic Behavior \& Organization 38 (3): 283-309.

Park, S.H., and G.R. Ungson. 1997. "The Effect of National Culture, Organizational Complementarity, and Economic Motivation on Joint Venture Dissolution." Academy of Management Journal: 279307.

Park, W.G. 2008. “International Patent Protection: 1960-2005.” Research Policy 37 (4): 761-766.

Parkhe, A. 1991. interfirm dicersity, organizational learning, and longevity in global strategic alliances. Journal of International Business Studies, 22, 4, 579-601.

Parkhe, A. 2003. "Institutional Environments, Institutional Change and International Alliances." Journal of International Management 9 (3): 305-316.

Peng, M. W., Ahlstrom, D., Carraher, S. M., \& Shi, W. S. (2017). An institution-based view of global IPR History. Journal of International Business Studies, 48(7), 893-907 
Pisano, G.P. 1990. "The R\&D Boundaries of the Firm: An Empirical Analysis." Administrative Science Quarterly 35 (1): 153-176.

Phelps C.C., 2010. A longitudinal study of the influence of alliance network structure and composition on firm exploratory innovation. Academy of Management Journal 53: 890-913.

Prahalad,, C. K., and G. Hamel, 1990. "The Core Competence of the Corporation." Harvard Business Review. http://hbr.org/1990/05/the-core-competence-of-the-corporation/ar/1.

Reuer J.J. and R. Ragozzino, 2006. Agency Hazards and Alliance Portfolios. Strategic Management Journal 27: 27-43.

Ronen, S., \& Shenkar, O. 2013. Mapping world cultures: Cluster formation, sources and implications. Journal of International Business Studies, 44(9), 867-897.

Rothaermel, F.T., and W. Boeker. 2008. "Old Technology Meets New Technology: Complementarities, Similarities, and Alliance Formation.” Strategic Management Journal 29 (1): 47-77.

Roy, JP., and C. Oliver. 2009. "International Joint Venture Partner Selection: The Role of the Hostcountry Legal Environment.” Journal of International Business Studies 40 (5): 779-801.

Sarala, R. M., Junni, P., Cooper, C. L., \& Tarba, S. Y., 2014. A sociocultural perspective on knowledge transfer in mergers and acquisitions. Journal of Management, 0149206314530167.

Scott, W.R. 2001. Institutions and Organizations. Sage Publications, Inc.

Schildt, H.A., M.V.J. Maula, and T. Keil. 2005. Explorative and exploitative learning from external corporate ventures. Entrepreneurship Theory and Practice, July, 1042-2587.

Schulze, M.S. \& N. Wolf, 2009. On the Origins of Border Effects: Evidence from the Habsburg Empire. Journal of Economic Geography 9(1):117-136.

Shah, R.H, \& V. Swaminathan. 2008. "Factors Influencing Partner Selection in Strategic Alliances: The Moderating Role of Alliance Context." Strategic Management Journal 29 (5): 471-494.

Shenkar, O. 2001. "Cultural Distance Revisited: Towards a More Rigorous Conceptualization and Measurement of Cultural Differences."Journal of International Business Studies: 519-35.

Shenkar, O. \& Zeira, Y. 1992. Role conflict and role ambiguity of Chief Executive Officers in international joint ventures, Journal of International Business Studies, 23, 1, 55-75

Stahl, G. K., Maznevski, M. L., Voigt, A., \& Jonsen, K. (2010). Unraveling the effects of cultural diversity in teams: A meta-analysis of research on multicultural work groups. Journal of international business studies, 41(4), 690-709.

Stahl, GK., \& Tung, R. L., 2014. Towards a more balanced treatment of culture in international business studies: the need for more positive cross-cultural scholarship. Journal of International Business Studies, 46, 4, 391-414.

Steensma, H.K., L. Marino, K.M. Weaver, and P.H. Dickson. 2000. "The Influence of National Culture on the Formation of Technology Alliances by Entrepreneurial Firms." Academy of Management Journal: 951-973.

Sull, D.N. 2001. "From Community of Innovation to Community of Inertia: The Rise and Fall of the US Tire Industry." In Academy of Management Proceedings, 1-6.

Szulanski, G. 1996. "Exploring Internal Stickiness: Impediments to the Transfer of Best Practice Within the Firm." Strategic Management Journal 17: 27-43.

Teece, David J. 1986. "Profiting from Technological Innovation: Implications for Integration, Collaboration, Licensing and Public Policy.” Research Policy 15 (6): 285-305.

Volkoff, O., D. M. Strong, and M.B. Elmes. 2007. "Technological Embeddedness and Organizational Change." Organization Science 18 (5): 832-848.

Vasudeva, G., Spencer, J. W., \& Teegen, H. J. (2013). Bringing the institutional context back in: A cross-national comparison of alliance partner selection and knowledge acquisition. Organization Science, 24(2), 319-338.

Wang, L., and E. J Zajac. 2007. "Alliance or Acquisition? A Dyadic Perspective on Interfirm Resource Combinations.” Strategic Management Journal 28 (13): 1291. 
Weber, Y., \& Tarba, S. Y. (2014). Strategic agility: a state of the art. California Management Review, 56(3), 5-12.

Williamson, O.E. 1975. Markets and hierarchies. NY: The Free Press.

Yamakawa, Y., Yang, H., and Lin, Z., 2011. "Exploration versus exploitation in alliance portfolio: Performance implications of organizational, strategic, and environmental fit", Research Policy 40: 287-296.

Xu, D., and O. Shenkar. 2002. "Institutional Distance and the Multinational Enterprise.” Academy of Management Review: 608-618.

Zaheer, S., M.S. Schomaker, \& L. Nachum. 2012. "Distance Without Direction: Restoring Credibility to a Much-loved Construct.” Journal of International Business Studies 43: 18-27.

Zhao, M. 2006. "Conducting R\&D in Countries with Weak Intellectual Property Rights Protection." Management Science 52 (8): 1185-1192. 


\begin{tabular}{|c|c|c|c|c|c|c|c|c|c|}
\hline Rank & Company & Country & Âverage sales & Percent Tires & No. Plants & No. Countries & R\&D spending & Employees & tnvestments \\
\hline$\overline{1}$ & Michelin & France & 10,892 & 93 & 56 & 14 & 735 & 128,165 & 1,290 \\
\hline 2 & Bridgestone & Japan & 9,703 & 75 & 44 & 19 & 354 & 102,165 & 1,573 \\
\hline 3 & Goodyear & USA & 9,616 & 86 & 45 & 22 & 449 & 106,724 & 805 \\
\hline 4 & Continental & Germany & 3,762 & 43 & 21 & 12 & 401 & 63,832 & 619 \\
\hline 5 & Sumitomo & Japan & 2,903 & 74 & 6 & 3 & 174 & 15,000 & 375 \\
\hline 6 & Pirelli & Italy & 2,712 & 45 & 18 & 10 & 216 & 41,954 & 500 \\
\hline 7 & Yokohama & Japan & 1,978 & 72 & 8 & 3 & 104 & 5,401 & 175 \\
\hline 8 & Toyo & Japan & 1,140 & 64 & 5 & 3 & 74 & 5,848 & 97 \\
\hline 9 & Cooper & USA & 1,138 & 53 & 5 & 2 & 40 & 21,185 & 150 \\
\hline 10 & Kumho & South Korea & 914 & 100 & 4 & 2 & 42 & 5,510 & 154 \\
\hline 11 & Hankook & South Korea & 826 & 95 & 4 & 2 & 51 & 4,152 & 128 \\
\hline
\end{tabular}

Table 1: Top global tire producers

Notes: (1) Average sales and percent of sales from tires are computed between 1984-2003 in million US\$; R\&D spending and investments (in million US\$), number of plants, number of countries in which these companies are present, and the number of employees, are all for 2003; (2) The top three tire producers worldwide account for almost half, while the top 11 producers account for about two thirds of the total R\&D expenditures in the industry. Source: various issues of the European Rubber Journal. 


\begin{tabular}{lcc}
\hline \hline Variable & Factor1 & Uniqueness \\
& Managerial Values \\
\hline \hline Competence of managers & $\mathbf{0 . 6 9}$ & $\mathbf{0 . 5 2}$ \\
Credibility of managers & $\mathbf{0 . 8 9}$ & $\mathbf{0 . 2 0}$ \\
Corporate boards effectiveness & $\mathbf{0 . 8 1}$ & $\mathbf{0 . 3 5}$ \\
Employee training & $\mathbf{0 . 7 7}$ & $\mathbf{0 . 4 0}$ \\
Flexibility and adaptability & 0.48 & 0.77 \\
International experience of management & $\mathbf{0 . 7 2}$ & $\mathbf{0 . 4 9}$ \\
Remuneration of management & 0.20 & 0.96 \\
Social responsibility & $\mathbf{0 . 8 3}$ & $\mathbf{0 . 3 1}$ \\
Worker's motivation & $\mathbf{0 . 8 9}$ & $\mathbf{0 . 2 1}$ \\
Eigenvalue & \multicolumn{2}{c}{4.53} \\
Alpha & \multicolumn{2}{c}{0.93} \\
\hline \hline
\end{tabular}

Table 2: Factor loadings of managerial values items form IMD WCY*

Note: * Bold type indicates best factored items

\begin{tabular}{|c|c|c|c|c|c|}
\hline Variable & Obs & Mean & Std. Dev. & Min & Max \\
\hline$\overline{\text { Partner selection exploit }}$ & $\overline{204,366}$ & 0.000 & 0.016 & 0.00 & $\overline{1.00}$ \\
\hline Partner selection explore & 204,366 & 0.002 & 0.043 & 0.00 & 1.00 \\
\hline Firm size differential* ${ }^{\star}$ & 204,366 & 10.614 & 1.756 & 0.00 & 14.82 \\
\hline Firm age differential ${ }^{*}$ & 204,366 & 3.022 & 0.951 & 0.00 & 4.77 \\
\hline Firm knowledge differential* & 204,366 & 0.759 & 1.607 & 0.00 & 6.86 \\
\hline Minority & 204,366 & 0.000 & 0.019 & 0.00 & 1.00 \\
\hline Majority & 204,366 & 0.001 & 0.024 & 0.00 & 1.00 \\
\hline JV & 204,366 & 0.001 & 0.027 & 0.00 & 1.00 \\
\hline Market size differential* & 204,366 & 1.622 & 1.104 & 0.00 & 6.51 \\
\hline Market growth differential & 204,366 & 0.041 & 0.035 & 0.00 & 0.24 \\
\hline Geographic contiguity & 204,366 & 0.065 & 0.247 & 0.00 & 1.00 \\
\hline Geographic distance* $^{*}$ & 204,366 & 8.890 & 0.700 & 5.09 & 9.88 \\
\hline Inverse Mills ratio & 204,366 & 3.565 & 0.377 & 1.95 & 3.90 \\
\hline Previous alliance experience & 204,366 & 0.162 & 0.933 & 0.00 & 10.00 \\
\hline Prior interactions & 204,366 & 0.002 & 0.044 & 0.00 & 1.00 \\
\hline Cognitive distance & 204,366 & 0.020 & 1.046 & -2.80 & 2.09 \\
\hline Normative distance & 204,366 & -0.082 & 0.850 & -1.25 & 4.45 \\
\hline Regulatory distance & 204,366 & 0.252 & 1.017 & -2.33 & 2.90 \\
\hline
\end{tabular}

Table 3: Descriptive statistics

Note: Variables marked with an * have followed a logarithmic transformation. 


\begin{tabular}{|c|c|c|c|c|c|c|c|c|c|c|c|}
\hline No & Variable & 1 & 2 & 3 & 4 & 5 & 6 & 7 & 8 & 9 & 10 \\
\hline 1 & Partner selection exploit & 1.00 & & & & & & & & & \\
\hline 2 & Partner selection explore & -0.00 & 1.00 & & & & & & & & \\
\hline 3 & Firm size differential & $0.03^{*}$ & -0.00 & 1.00 & & & & & & & \\
\hline 4 & Firm age differential & $0.02^{*}$ & -0.00 & $0.09^{*}$ & 1.00 & & & & & & \\
\hline 5 & Firm knowledge differential & $0.09^{*}$ & $0.02^{*}$ & $0.33^{*}$ & $0.10^{*}$ & 1.00 & & & & & \\
\hline 6 & Minority & $0.36^{*}$ & $0.03^{*}$ & $0.01^{*}$ & $0.01^{*}$ & $0.04^{*}$ & 1.00 & & & & \\
\hline 7 & Majority & $0.44^{*}$ & $0.06^{*}$ & $0.02^{*}$ & $0.01^{*}$ & $0.06^{*}$ & $0.01^{*}$ & 1.00 & & & \\
\hline 8 & JV & $0.37^{*}$ & $0.25^{\star}$ & $0.03^{*}$ & $0.01^{*}$ & $0.08^{*}$ & $0.04^{*}$ & $0.17^{*}$ & 1.00 & & \\
\hline 9 & Market size differential & $0.01^{*}$ & $-0.01^{*}$ & $0.10^{*}$ & $0.01^{*}$ & $0.12^{*}$ & -0.00 & 0.00 & 0.00 & 1.00 & \\
\hline 10 & Market growth differential & $0.01^{*}$ & $-0.01^{*}$ & $-0.04^{*}$ & $0.04^{*}$ & $-0.06^{*}$ & $0.01^{*}$ & $-0.01^{*}$ & -0.00 & $-0.02^{*}$ & 1.00 \\
\hline 11 & Geographic contiguity & $-0.01^{*}$ & -0.00 & $0.01^{*}$ & $-0.06^{*}$ & $-0.05^{*}$ & 0.00 & $-0.01^{*}$ & $-0.01^{*}$ & * $-0.10^{*}$ & $-0.09^{*}$ \\
\hline 12 & Geographic distance & 0.00 & 0.00 & $0.01^{*}$ & $0.04^{*}$ & $-0.01^{*}$ & 0.00 & 0.00 & $0.01^{*}$ & $0.07^{*}$ & $0.13^{*}$ \\
\hline 13 & Inverse Mills ratio & $-0.12^{*}$ & $-0.05^{\star}$ & $-0.25^{*}$ & $-0.17^{*}$ & $-0.74^{*}$ & 0.04 & $-0.08^{*}$ & $-0.08^{*}$ & * $-0.08^{*}$ & $0.06^{*}$ \\
\hline 14 & Previous alliance experience & $0.07^{*}$ & $0.01^{*}$ & $0.07^{*}$ & $0.05^{*}$ & $0.28^{*}$ & 0.01 & $0.02^{*}$ & $0.01^{*}$ & $0.017^{\star}$ & $-0.02^{*}$ \\
\hline 15 & Prior interactions & $0.76^{*}$ & $0.27^{*}$ & $0.03^{*}$ & $0.01^{*}$ & $0.08^{*}$ & 0.30 & $0.38^{*}$ & $0.45^{\star}$ & $0.00^{*}$ & $0.01^{*}$ \\
\hline 16 & Cognitive distance & $-0.02^{*}$ & $0.02^{*}$ & $-0.05^{*}$ & $-0.06^{*}$ & $0.01^{*}$ & 0.00 & $0.01^{*}$ & -0.00 & $0.01^{*}$ & $-0.08^{*}$ \\
\hline 17 & Normative distance & $-0.01^{*}$ & -0.00 & $0.05^{*}$ & $0.02^{*}$ & $0.02^{*}$ & $-0.01^{*}$ & 0.00 & -0.00 & $0.08^{*}$ & $-0.02^{*}$ \\
\hline 18 & Regulatory distance & -0.00 & $0.02^{*}$ & 0.00 & $0.03^{*}$ & $0.20^{*}$ & 0.00 & $0.01^{*}$ & $0.01^{*}$ & $0.11^{*}$ & $-0.07^{*}$ \\
\hline No & Variable & 11 & 12 & 13 & 14 & 15 & 16 & 17 & 18 & & \\
\hline 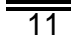 & "Geographic contiguity & $\overline{17.00}$ & & & & & & & & & \\
\hline 12 & Geographic distance & $-0.41^{*}$ & 1.00 & & & & & & & & \\
\hline 13 & Inverse Mills ratio & $0.06^{*}$ & $0.03^{*}$ & 1.00 & & & & & & & \\
\hline 14 & Previous alliance experience & $-0.02^{*}$ & -0.00 & $-0.37^{*}$ & 1.00 & & & & & & \\
\hline 15 & Prior interactions & $-0.01^{*}$ & 0.00 & $-0.12^{*}$ & $0.06^{*}$ & 1.00 & & & & & \\
\hline 16 & Cognitive distance & -0.00 & $0.02^{\star}$ & $0.12^{*}$ & -0.00 & $-0.01^{*}$ & 1.00 & & & & \\
\hline 17 & Normative distance & $-0.07^{\star}$ & 0.00 & $-0.03^{*}$ & $-0.03^{*}$ & $-0.01^{*}$ & $-0.01^{*}$ & 1.00 & & & \\
\hline 18 & Regulatory distance & $-0.08^{\star}$ & $0.10^{*}$ & $-0.06^{*}$ & -0.00 & $0.01^{*}$ & $0.15^{*}$ & $0.03^{*}$ & 1.00 & & \\
\hline
\end{tabular}

Note: * denotes correlations significant at 5 percent or better

Table 4: Paired correlations 


\begin{tabular}{|c|c|c|c|c|c|c|c|c|c|c|}
\hline Variables / Models & Model 1 & Model 2 & Model 3 & Model 4 & Model 5 & Model 6 & Model 7 & Model 8 & Model 9 & Model 10 \\
\hline & & & Exploit & & & \multicolumn{5}{|c|}{ Explore } \\
\hline Firm size differential & $\begin{array}{l}0.13+ \\
{[0.08]}\end{array}$ & $\begin{array}{l}0.11 \\
{[0.08]}\end{array}$ & $\begin{array}{l}0.12 \\
{[0.07]}\end{array}$ & $\begin{array}{l}0.13+ \\
{[0.08]}\end{array}$ & $\begin{array}{l}0.10 \\
{[0.07]}\end{array}$ & $\begin{array}{l}-0.24+ \\
{[0.13]}\end{array}$ & $\begin{array}{l}-0.26 \\
{[0.16]}\end{array}$ & $\begin{array}{c}-0.26^{* \pi} \\
{[0.12]}\end{array}$ & $\begin{array}{l}-0.24+ \\
{[0.13]}\end{array}$ & $\begin{array}{l}-0.28+ \\
{[0.16]}\end{array}$ \\
\hline Firm age differential & $\begin{array}{c}0.01 \\
{[0.21]}\end{array}$ & $\begin{array}{l}-0.04 \\
{[0.20]}\end{array}$ & $\begin{array}{c}0.01 \\
{[0.21]}\end{array}$ & $\begin{array}{c}0.00 \\
{[0.21]}\end{array}$ & $\begin{array}{l}-0.07 \\
{[0.20]}\end{array}$ & $\begin{array}{c}-1.19^{* \star *} \\
{[0.24]}\end{array}$ & $\begin{array}{l}-0.45 \\
{[0.27]}\end{array}$ & $\begin{array}{c}-1.18^{* * *} \\
{[0.22]}\end{array}$ & $\begin{array}{c}-1.04^{\star * *} \\
{[0.25]}\end{array}$ & $\begin{array}{l}-0.43 \\
{[0.26]}\end{array}$ \\
\hline Firm knowledge differential & $\begin{array}{c}0.01 \\
{[0.09]}\end{array}$ & $\begin{array}{c}0.02 \\
{[0.10]}\end{array}$ & $\begin{array}{c}0.02 \\
{[0.09]}\end{array}$ & $\begin{array}{c}0.02 \\
{[0.10]}\end{array}$ & $\begin{array}{c}0.04 \\
{[0.11]}\end{array}$ & $\begin{array}{c}-1.31^{* * *} \\
{[0.28]}\end{array}$ & $\begin{array}{c}-1.58^{\star * *} \\
{[0.23]}\end{array}$ & $\begin{array}{c}-1.34^{* * *} \\
{[0.26]}\end{array}$ & $\begin{array}{c}-1.20^{* * *} \\
{[0.28]}\end{array}$ & $\begin{array}{c}-1.54^{* * *} \\
{[0.23]}\end{array}$ \\
\hline Minority & $\begin{array}{c}8.45^{* * *} \\
{[0.79]}\end{array}$ & $\begin{array}{c}8.45^{\star * *} \\
{[0.76]}\end{array}$ & $\begin{array}{c}8.51^{* * *} \\
{[0.77]}\end{array}$ & $\begin{array}{c}8.41^{* * *} \\
{[0.78]}\end{array}$ & $\begin{array}{c}8.45^{\star \star *} \\
{[0.76]}\end{array}$ & $\begin{array}{c}-5.02^{* \star *} \\
{[1.73]}\end{array}$ & $\begin{array}{c}-5.81^{* \star *} \\
{[1.69]}\end{array}$ & $\begin{array}{c}-4.23^{* *} \\
{[1.76]}\end{array}$ & $\begin{array}{c}-5.46^{\star * *} \\
{[1.56]}\end{array}$ & $\begin{array}{c}-5.65^{\star \star *} \\
{[1.67]}\end{array}$ \\
\hline Majority & $\begin{array}{c}7.26^{* \star *} \\
{[0.83]}\end{array}$ & $\begin{array}{c}7.08^{\star * *} \\
{[0.57]}\end{array}$ & $\begin{array}{c}7.51^{* * *} \\
{[0.97]}\end{array}$ & $\begin{array}{c}7.15^{\star * *} \\
{[0.81]}\end{array}$ & $\begin{array}{c}7.13^{\star \star *} \\
{[0.61]}\end{array}$ & $\begin{array}{c}7.71^{* * *} \\
{[1.15]}\end{array}$ & $\begin{array}{c}10.10^{* * *} \\
{[1.77]}\end{array}$ & $\begin{array}{c}8.65^{\star \star *} \\
{[1.24]}\end{array}$ & $\begin{array}{c}6.46^{* * *} \\
{[1.19]}\end{array}$ & $\begin{array}{c}10.58^{\star \star *} \\
{[2.04]}\end{array}$ \\
\hline JV & $\begin{array}{c}4.77^{\star * *} \\
{[0.53]}\end{array}$ & $\begin{array}{c}4.84^{\star * *} \\
{[0.56]}\end{array}$ & $\begin{array}{c}4.92^{* * *} \\
{[0.54]}\end{array}$ & $\begin{array}{c}4.77^{* * *} \\
{[0.52]}\end{array}$ & $\begin{array}{c}5.03^{\star \star \star} \\
{[0.57]}\end{array}$ & $\begin{array}{c}7.18^{* * *} \\
{[1.26]}\end{array}$ & $\begin{array}{c}8.25^{\star \star \star} \\
{[1.29]}\end{array}$ & $\begin{array}{c}7.20^{\star \star \star} \\
{[1.24]}\end{array}$ & $\begin{array}{c}6.77^{\star \star *} \\
{[1.27]}\end{array}$ & $\begin{array}{c}8.11^{\star \star \star} \\
{[1.32]}\end{array}$ \\
\hline Market size differential & $\begin{array}{c}0.07 \\
{[0.17]}\end{array}$ & $\begin{array}{c}0.05 \\
{[0.16]}\end{array}$ & $\begin{array}{c}0.04 \\
{[0.18]}\end{array}$ & $\begin{array}{c}0.06 \\
{[0.17]}\end{array}$ & $\begin{array}{c}0.03 \\
{[0.18]}\end{array}$ & $\begin{array}{c}-1.96^{* * *} \\
{[0.39]}\end{array}$ & $\begin{array}{c}-2.72^{\star * \star} \\
{[0.81]}\end{array}$ & $\begin{array}{c}-1.80^{* * *} \\
{[0.35]}\end{array}$ & $\begin{array}{c}-2.18^{\star \star \star} \\
{[0.39]}\end{array}$ & $\begin{array}{c}-2.35^{\star \star *} \\
{[0.71]}\end{array}$ \\
\hline Market growth differential & $\begin{array}{c}13.97^{* * *} \\
{[3.33]}\end{array}$ & $\begin{array}{c}9.59^{* * *} \\
{[3.35]}\end{array}$ & $\begin{array}{c}14.42^{* * *} \\
{[3.08]}\end{array}$ & $\begin{array}{c}13.71^{* * *} \\
{[3.32]}\end{array}$ & $\begin{array}{c}9.68^{* * *} \\
{[2.94]}\end{array}$ & $\begin{array}{c}-78.96^{* * *} \\
{[20.42]}\end{array}$ & $\begin{array}{c}-117.95^{\star * *} \\
{[24.07]}\end{array}$ & $\begin{array}{c}-78.11^{* * *} \\
{[19.74]}\end{array}$ & $\begin{array}{r}-86.84^{* * *} \\
{[20.68]}\end{array}$ & $\begin{array}{r}-115.53^{* \star *} \\
{[21.73]}\end{array}$ \\
\hline Geographic contiguity & $\begin{array}{c}0.13 \\
{[0.72]}\end{array}$ & $\begin{array}{l}-0.21 \\
{[0.66]}\end{array}$ & $\begin{array}{c}0.13 \\
{[0.70]}\end{array}$ & $\begin{array}{c}0.16 \\
{[0.71]}\end{array}$ & $\begin{array}{l}-0.17 \\
{[0.65]}\end{array}$ & $\begin{array}{c}1.10 \\
{[0.96]}\end{array}$ & $\begin{array}{c}1.08 \\
{[1.76]}\end{array}$ & $\begin{array}{c}0.57 \\
{[1.01]}\end{array}$ & $\begin{array}{c}1.46 \\
{[1.03]}\end{array}$ & $\begin{array}{c}0.76 \\
{[1.78]}\end{array}$ \\
\hline Geographic distance & $\begin{array}{l}-0.18 \\
{[0.21]}\end{array}$ & $\begin{array}{c}-0.25 \\
{[0.23]}\end{array}$ & $\begin{array}{l}-0.16 \\
{[0.21]}\end{array}$ & $\begin{array}{c}-0.15 \\
{[0.21]}\end{array}$ & $\begin{array}{l}-0.20 \\
{[0.21]}\end{array}$ & $\begin{array}{c}2.44^{* * *} \\
{[0.49]}\end{array}$ & $\begin{array}{c}2.66^{\star * \star} \\
{[0.96]}\end{array}$ & $\begin{array}{c}2.33^{\star \star \star} \\
{[0.41]}\end{array}$ & $\begin{array}{c}2.77^{\star \star *} \\
{[0.50]}\end{array}$ & $\begin{array}{l}2.40^{\star *} \\
{[0.97]}\end{array}$ \\
\hline Inverse Mills ratio & $\begin{array}{c}-2.15 \\
{[0.343]}\end{array}$ & $\begin{array}{c}-2.10^{* * *} \\
{[0.41]}\end{array}$ & $\begin{array}{c}-2.14^{* * *} \\
{[0.34]}\end{array}$ & $\begin{array}{c}-2.14^{* * *} \\
{[0.36]}\end{array}$ & $\begin{array}{c}-2.06^{* * *} \\
{[0.45]}\end{array}$ & $\begin{array}{c}-9.87^{\star * *} \\
{[0.98]}\end{array}$ & $\begin{array}{c}-11.07^{* * *} \\
{[1.43]}\end{array}$ & $\begin{array}{c}-9.92^{* * *} \\
{[0.99]}\end{array}$ & $\begin{array}{c}-9.07^{* * *} \\
{[0.95]}\end{array}$ & $\begin{array}{c}-10.62^{\star \star \star} \\
{[1.50]}\end{array}$ \\
\hline Previous alliance experience & $\begin{array}{c}0.34^{* * *} \\
{[0.05]}\end{array}$ & $\begin{array}{c}0.36^{* * *} \\
{[0.05]}\end{array}$ & $\begin{array}{c}0.35^{* * *} \\
{[0.05]}\end{array}$ & $\begin{array}{c}0.34^{* * *} \\
{[0.05]}\end{array}$ & $\begin{array}{c}0.36^{\star * *} \\
{[0.05]}\end{array}$ & $\begin{array}{c}-0.31^{* * *} \\
{[0.11]}\end{array}$ & $\begin{array}{c}-0.58^{\star * *} \\
{[0.13]}\end{array}$ & $\begin{array}{c}-0.37^{* * *} \\
{[0.12]}\end{array}$ & $\begin{array}{c}-0.26^{* *} \\
{[0.11]}\end{array}$ & $\begin{array}{c}-0.59^{* * *} \\
{[0.14]}\end{array}$ \\
\hline Prior interactions & $\begin{array}{c}8.65^{\star * *} \\
{[0.46]}\end{array}$ & $\begin{array}{c}8.85^{\star * *} \\
{[0.51]}\end{array}$ & $\begin{array}{c}8.77^{* * *} \\
{[0.51]}\end{array}$ & $\begin{array}{c}8.66^{* * *} \\
{[0.46]}\end{array}$ & $\begin{array}{c}8.99^{\star \star *} \\
{[0.54]}\end{array}$ & $\begin{array}{c}4.77^{\star \star \star} \\
{[0.49]}\end{array}$ & $\begin{array}{c}4.61^{* \star *} \\
{[0.81]}\end{array}$ & $\begin{array}{c}4.67^{\star \star \star} \\
{[0.51]}\end{array}$ & $\begin{array}{c}4.92^{\star \star \star} \\
{[0.49]}\end{array}$ & $\begin{array}{c}4.52^{\star \star \star} \\
{[0.75]}\end{array}$ \\
\hline Cognitive distance & & $\begin{array}{c}-0.47^{\star \star *} \\
{[0.12]}\end{array}$ & & & $\begin{array}{c}-0.45^{\star \star *} \\
{[0.13]}\end{array}$ & & $\begin{array}{c}4.78^{\star \star \star} \\
{[0.83]}\end{array}$ & & & $\begin{array}{c}4.76^{\star \star *} \\
{[0.91]}\end{array}$ \\
\hline Normative distance & & & $\begin{array}{c}-0.29^{* *} \\
{[0.12]}\end{array}$ & & $\begin{array}{c}-0.25^{\star *} \\
{[0.12]}\end{array}$ & & & $\begin{array}{c}-0.68^{\star *} \\
{[0.28]}\end{array}$ & & $\begin{array}{c}-0.53+ \\
{[0.32]}\end{array}$ \\
\hline Regulatory distance & & & & $\begin{array}{c}-0.17^{\star *} \\
{[0.08]}\end{array}$ & $\begin{array}{c}-0.10^{* *} \\
{[0.05]}\end{array}$ & & & & $\begin{array}{c}1.53^{\star \star *} \\
{[0.18]}\end{array}$ & $\begin{array}{c}0.18 \\
{[0.28]}\end{array}$ \\
\hline $\begin{array}{l}\mathrm{N} \\
\text { Pseudo R-square }\end{array}$ & $\begin{array}{c}204,366 \\
0.745\end{array}$ & $\begin{array}{c}204,366 \\
0.754\end{array}$ & $\begin{array}{c}204,366 \\
0.746\end{array}$ & $\begin{array}{c}204,366 \\
0.748\end{array}$ & $\begin{array}{c}204,366 \\
0.756\end{array}$ & $\begin{array}{c}204,366 \\
0.666\end{array}$ & $\begin{array}{c}204,366 \\
0.730\end{array}$ & $\begin{array}{c}204,366 \\
0.666\end{array}$ & $\begin{array}{c}204,366 \\
0.704\end{array}$ & $\begin{array}{c}204,366 \\
0.740\end{array}$ \\
\hline
\end{tabular}

Table 5: Institutional distance and partner selection for exploitation and exploration alliances. Rare-event logistic regression

Notes: The dependent variable (Exploit, Explore) equals 1 if the potential partner in the dyad is selected for an exploitation (respectively exploration) technological alliance, and 0 otherwise; All models include time dummies and an intercept, which not reported here due to space constraints; Standard errors are clustered on the dyad.,$+{ }^{* *}$ and ${ }^{* * *}$ indicate variables that are significant at the $10 \%, 5 \%$ and respectively $1 \%$. 


\section{Appendix.}

\begin{tabular}{|c|c|c|c|c|}
\hline Coding & Information & Year & Focal firm & Partner(s) \\
\hline Exploration & $\begin{array}{l}\text { Sumitomo will participate in technology exchanges with BTR-Dunlop via the } \\
\text { global operations of the Dunlop Group }\end{array}$ & 1993 & $\begin{array}{l}\text { Sumitomo Rubber } \\
\text { Industries (Japan) }\end{array}$ & BTR-Dunlop (UK) \\
\hline Exploration & $\begin{array}{l}\text { This agreement aims at setting an industry standard and broadening the appeal } \\
\text { and availability for run-flat tires; it consists of jointly operated R\&D operations } \\
\text { based in the Netherlands and license each other's respective run-flat } \\
\text { technologies. Goodyear has developed run-flat technology that mounts on a } \\
\text { conventional rim, while Michelin has an integrated wheel-and-tire system. }\end{array}$ & 2000 & $\begin{array}{l}\text { Goodyear Tire \& } \\
\text { Rubber Co. (USA) }\end{array}$ & $\begin{array}{l}\text { Group Michelin SA } \\
\text { (France) }\end{array}$ \\
\hline Exploration & $\begin{array}{l}\text { Pirelli and Continental cooperate on developing new tyre truck technologies and } \\
\text { have signed an off-take production agreement }\end{array}$ & 2003 & $\begin{array}{l}\text { Continental AG } \\
\text { (Germany) }\end{array}$ & Pirelli Group (Italy) \\
\hline Exploration & $\begin{array}{l}\text { Pirelli, Goodyear, Sumitomo, Hankook and Michelin cooperate on the } \\
\text { development of Michelin's PAX run-flat tire-wheel system }\end{array}$ & 2003 & $\begin{array}{l}\text { Group Michelin SA } \\
\text { (France) }\end{array}$ & Pirelli Group (Italy) \\
\hline Exploration & $\begin{array}{l}\text { Nokian shares some of its tire technology with Bridgestone Corp. which holds } \\
18.9 \text { percent stake in the company. }\end{array}$ & 2002 & Nokian (Finland) & $\begin{array}{l}\text { Bridgestone Corp. } \\
\text { (Japan) }\end{array}$ \\
\hline Exploitation & $\begin{array}{l}\text { Vredestein has signed a long-term agreement to licence the technology and } \\
\text { production of Vredestein brand tyres to PT Elganperdana. }\end{array}$ & 1997 & $\begin{array}{l}\text { Vredestein } \\
\text { (Netherlands) }\end{array}$ & $\begin{array}{l}\text { PT Elganperdana } \\
\text { (Indonesia) }\end{array}$ \\
\hline Exploitation & $\begin{array}{l}\text { Sumitomo Rubber will provide turnkey and process technology on a contractual } \\
\text { basis to Bonsa Tyre, Chongqing Tyre Factory and Liaoning Tyre via BTR Dunlop } \\
\text { Ltd in South Africa, which is overseeing the former Dunlop International Technical } \\
\text { and Trading Services in Birmingham, UK. }\end{array}$ & 1997 & $\begin{array}{l}\text { Sumitomo Rubber } \\
\text { Industries Ltd. } \\
\text { (Japan) }\end{array}$ & $\begin{array}{l}\text { Bonsa Tyre co Ltd } \\
\text { (Ghana); Chongqing } \\
\text { Tyre Factory (China); } \\
\text { Liaoning Tyre } \\
\text { (China). }\end{array}$ \\
\hline Exploitation & $\begin{array}{l}\text { Continental will outsource many of its motorcycle and scooter tires to Metro Tyres' } \\
\text { dedicated new plant in Ludhiana, India. Also, the partners have signed long-term } \\
\text { agreements covering both off-take production and technological support. }\end{array}$ & 2002 & $\begin{array}{l}\text { Continental AG } \\
\text { (Germany) }\end{array}$ & $\begin{array}{l}\text { Metro Tyres Ltd } \\
\text { (India) }\end{array}$ \\
\hline Exploitation & $\begin{array}{l}\text { Michelin has formed a joint venture with Tigar } A D \text { to make and market tyres and } \\
\text { tubes in Yugoslavia. In addition Michelin will provide tire technology to Tigar AD. }\end{array}$ & 2003 & $\begin{array}{l}\text { Group Michelin SA } \\
\text { (France) }\end{array}$ & Tigar AD (Serbia) \\
\hline
\end{tabular}

Table 6: Examples of technological alliances considered and coding choices 